Georgia State University

ScholarWorks @ Georgia State University

Sociology Theses

Department of Sociology

Summer 8-21-2013

\title{
Obscuring Sexual Crime: Examining Media Representations of Sexual Violence in Megan's Law
}

Renee M. Shelby

Follow this and additional works at: https://scholarworks.gsu.edu/sociology_theses

\section{Recommended Citation}

Shelby, Renee M., "Obscuring Sexual Crime: Examining Media Representations of Sexual Violence in Megan's Law." Thesis, Georgia State University, 2013.

doi: https://doi.org/10.57709/4489961

This Thesis is brought to you for free and open access by the Department of Sociology at ScholarWorks @ Georgia State University. It has been accepted for inclusion in Sociology Theses by an authorized administrator of ScholarWorks @ Georgia State University. For more information, please contact scholarworks@gsu.edu. 


\title{
OBSCURING SEXUAL CRIME:
}

EXAMINING MEDIA REPRESENTATIONS OF SEXUAL VIOLENCE IN MEGAN'S LAW

by

RENEE MARIE SHELBY

Under the Direction of Anthony Hatch

\begin{abstract}
Sexual violence remains a pervasive and persistent social problem. In 1996, Congress enacted Megan's Law, dictating mandatory community notification and potential civil commitment for those deemed by the State to be “dangerous sexual offenders." In 2013, Megan's law continues to influence the treatment of sexual offenders under law and the social construction of a highly publicized, yet statistically rare, sexual crime - the rape and murder of a young female child by a depraved male stranger. This influence highlights the extent to which this personalized crime bill shapes the social construction of sexual violence in terms of sex and gender systems. This project examines how sex and gender shape media discourses of the sexual offender and victim that are mobilized in the legislative debate on Megan's Law. Drawing on theoretical ideas from cultural studies and feminist legal scholarship, I employ discourse analysis to analyze the legislative debate on Megan's Law.
\end{abstract}

INDEX WORDS: Media, Gender and sexuality, Sex crime legislation, Discourse analysis, Megan's law 



\section{OBSCURING SEXUAL CRIME:}

EXAMINING MEDIA REPRESENTATIONS OF SEXUAL VIOLENCE IN MEGAN'S LAW

by

RENEE MARIE SHELBY

A Thesis Submitted in Partial Fulfillment of the Requirements for the Degree of Master of Arts

in the College of Arts and Sciences

Georgia State University

2013 

Copyright by

Renee Marie Shelby

2013 



\section{OBSCURING SEXUAL CRIME:}

EXAMINING MEDIA REPRESENTATIONS OF SEXUAL VIOLENCE IN MEGAN'S LAW

by

\section{RENEE MARIE SHELBY}

Committee Chair: Anthony Hatch

Committee: $\quad$ Lesley Reid

Wendy Simonds

Electronic Version Approved:

Office of Graduate Studies

College of Arts and Sciences

Georgia State University

August 2013 



\section{ACKNOWLEDGEMENTS}

Thanks to the coolest father, Command Sergeant Major David Shelby, for being extremely supportive and loving- both now and then. For continued mentoring, guidance, and inspiration, I deeply appreciate my committee Dr. Anthony Hatch, Dr. Lesley Reid, and Dr. Wendy Simonds. Also, the generosity of spirit, time, and support from Dr. Griff Tester, Dr. Dawn Banauch, and others in the Sociology Department at Georgia State University do not go unappreciated. For general emotional support, love, and encouragement, I thank Tyler Kennedy and Logan Kloepfer. 


\section{TABLE OF CONTENTS}

ACKNOWLEDGEMENTS .. $\mathrm{v}$

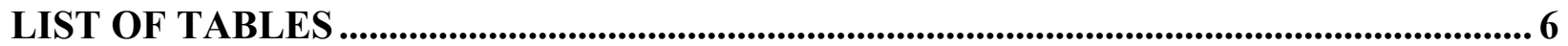

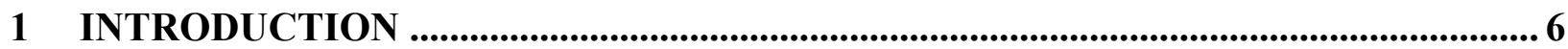

1.1 Research Questions................................................................................ 6

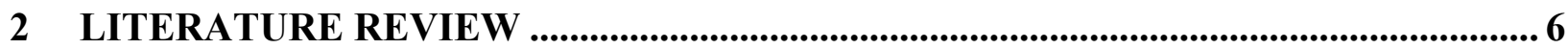

2.1 The Social Construction of Sexual Scripts: “Normalcy" vs. “Deviancy"............ 6

2.1.1 Constructing Deviant Behavior: A History of Selective Legislation ... 6

2.1.2 Constructing the Sexual Offender ...................................................6

2.2 Cultural Studies: The Role of Media in Shaping Sexual Abuse Scripts ............... 6

2.2.1 Media Influence and Disseminating the Image of Sexual Abuse......... 6

2.2.2 Media Templates: Solidifying the Perverted Predator........................... 6

2.3 Feminist Analyses of Sex Crimes and Sex Crimes Law................................... 6

2.3.1 Feminist Reformers: A Brief Period of Enlightenment......................... 6

2.3.2 Sexual Predator Laws: A Return to the Old Architecture .................... 6

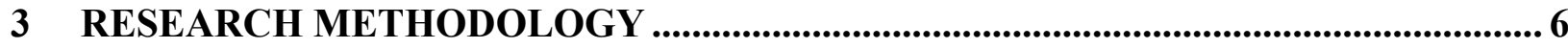

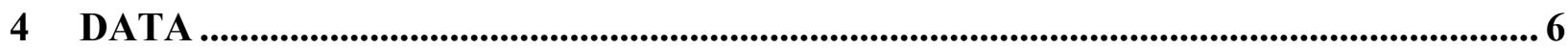

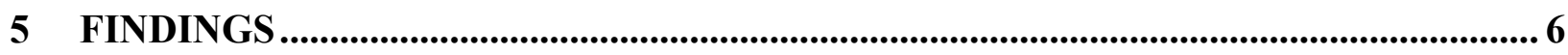

5.1 Focus on Specific Types of Child Victims.................................................... 6

5.2 Sexual Psychopath Rhetoric ..................................................................... 6

5.3 Discourse Homogeneity Through Disconfirming Evidence ............................... 6

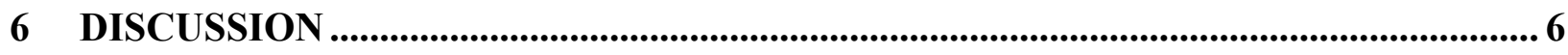

7 CONCLUSION

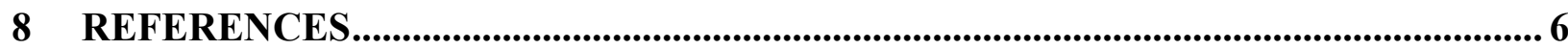

9 APPENDIX 


\section{LIST OF TABLES}

Table 1.1 Sex Offender Guidelines for Classification and Notification Under Megan's

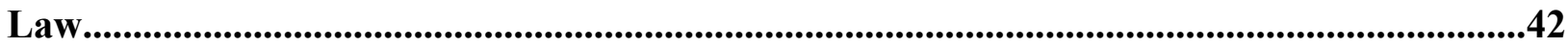

Table A.1: Frequency of "Sexual Predator" and "Sex Offender" in U.S. Newspaper

Headlines, Leads, \& Subject Terms, 1990-2006.............................................................44

Table A.2: Number of Rape/Sexual Assaults in the United States: Self-Reports and

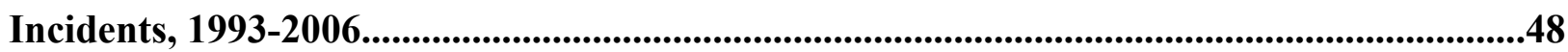




\section{INTRODUCTION}

On July 29, 1994, seven-year-old Megan Kanka was raped and murdered by a neighbor in Hamilton Township, NJ. Jesse Timmendequas, previously convicted of raping two young girls, lived across the street from the Kanka family. He lured Megan into the house by offering to show her a puppy. He then strangled her with a belt, raped her twice, and suffocated her with a plastic bag. Afterwards, Timmendequas placed her body in a chest and dumped it in a park. Within hours of Megan's disappearance the Kanka's alerted the authorities and held a news conference pleading for their daughter's return. The police questioned Timmendequas and he confessed the next day. The Kanka's were outraged that a convicted sex offender lived across the street. They launched a media-driven, statewide movement to reform sex offender laws arguing it is "a parent's right to know" the whereabouts of sexual predators (Megan's Law 2012). They asserted, "if we had been aware of [Timmendequas's] record, our daughter would be alive today" (Megan's Law 2012). Letters of support and memorial fund contributions poured into the Kanka home. Over 400,000 citizens signed a petition demanding a legislative response. One month after the murder, New Jersey passed the first Megan's Law, requiring convicted sex offenders to alert police when they move into a community (McLarin 1994). In 1996, Congress amended the Jacob Wetterling Crimes Against Children and Sexually Violent Offender Registration Act to require all states to enact Megan's Law, dictating mandatory community notification and potential civil commitment for those deemed by the State to be "dangerous sexual offenders."

\footnotetext{
${ }^{1}$ Community notification requires law enforcement to make information regarding registered sex offenders available to the public. Individual states decide what information must be available, but this typically includes: the offender's name, picture, address, incarceration date, and nature of the crime. Before the widespread advent of the Internet, notification primarily occurred through CD-ROMs. Now this information is available on a variety of for profit and government websites. A notification requirement may be imposed from between 10 years to life.
} 
For both proponents and opponents, Megan's Law is considered landmark sex crime legislation. ${ }^{2}$ It combines "some of the oldest forms of punishment—shaming, marking, and exclusion — with some of the newest—risk prediction, psychological assessment, and information management" (Corrigan 2006:268). ${ }^{3}$ Upon signing the bill into law, President Bill Clinton declared, "Today, America warns: If you dare prey on our children, the law will follow you wherever you go state to state, town to town" (Milwaukee Journal 1996). Signaling its endurance, more than 15 years later, Megan's Law continues to garner immense public and governmental support, significant tax fund allocation, media coverage, and impacts public institutions and spaces (Corrigan 2006). In 2011, the $112^{\text {th }}$ Congress introduced a bill to enact an international Megan's Law aimed to track both domestically convicted offenders traveling abroad and known foreign offenders entering the United States. As evidenced by this continued structural and social salience, Megan's Law is arguably one of the most important developments in sex crime law since feminist-led anti-rape reform in the 1970s.

Given the widespread media coverage of and public support for Megan’s Law, it would seem likely that this law would be based upon the most threatening type of sexual violence. However, empirically, the circumstances of Megan's death constitute one of the least likely ways that sexual violence occurs. According to the U.S. Department of Justice's National Crime Victimization Survey (NCVS 2000), there are approximately 207,754 sexual assaults every year. Children under the age of 12 account for $34 \%$ of sexual violence victims, and children under the age of 6 account for $14 \%$ of victims. For adults, victimization is more likely to occur by stranger,

\footnotetext{
${ }^{2}$ In general, sex crime laws proscribe which sexual acts are considered either to be sexual abuse or behaviors that society deems to be inappropriate. For this paper, terms such as sex crime, sexual violence, and sexual offender will be used interchangeably to indicate a person or crime of an non-consenting, sexually violent nature.

${ }^{3}$ Sex offender risk assessment is a way of estimating the statistical probability that an offender will commit another sexual offense. The most widely used tool is the static-99R-a test developed for the use of male adult sexual offenders 18-years of age or older. A copy of the static-99r coding form is available in the Appendix.
} 
accounting for $27 \% .{ }^{4}$ However, only $3 \%$ of offenders in the sexual assaults of children were strangers. Though the NCVS does track concurrent offenses in sexual assault incidents, no data were collected on the assault and murder of young victims. In fact, the age of the victim is negatively related with the likelihood of being killed in a violent crime, whether of a sexual nature or not. According to 1997 Bureau of Justice statistics, victims of murder are the oldest of serious violent crime victims. Conversely, victims under the age of 12 account for less than 0.5 per 1,000 persons. No matter how infrequent, violent crime is a serious offense. However, basing massive sex crime legislation on one particular concept of sexual violence is problematic, as it ignores other types of sexual assault and discourages victims to speak out against more widespread and taken-for-granted forms of sexual violence. ${ }^{5}$

The foundation of Megan's Law draws on the culturally constructed notion of the sexual offender. Since the 1930s, the mass media have played a key role in shaping the broader discourse on sexual abuse, giving inordinate attention to the rare sexual assault and murder of young children by "sexual psychopaths" (Bourke 2007). For example, in American Magazine, J. Edgar Hoover (1947:32) warned that sexual psychopaths were responsible for a wave of crimes, asserting, "depraved human beings, more savage than beasts, are permitted to rove America almost at will...the nation's women and children will never be secure...so long as degenerates run wild." This model continued to shape dominant notions of assault, whereby it was not uncommon to think, "if a rapist cannot be labeled a fiend, monster, or maniac, then it probably isn't rape at all” (Toner 1977:47). This particular construction of the sex offender draws on cultural ideas of sexuality and gender that erect a framework of sexual violence that situates

\footnotetext{
${ }^{4}$ It is important to note that "more likely" does not mean "most likely." Though $27 \%$ of adult victims do not know their attackers, $83 \%$ do.

${ }^{5}$ The major goal of Megan's Law is to require States to publicly list information about convicted sexual offenders in the name of self-protection. Presumably, the lists allow people to identify sexually dangerous persons. However, the lists fail to identify persons who were neither charged nor convicted, persons who were able to obtain plea negotiations that allowed them not to be listed, or persons convicted of incestual crimes.
} 
sexual assault in risky public spaces at the hands of depraved male maniacs, rather than the result of everyday intimate relationships at the hands of assumed loved ones. The case of Megan Kanka reflects this construction of assault, maintaining the myth that male strangers perpetrate sexual violence against young girls in public spaces. This narrow construction of sexual violence discourages victims of everyday forms sexual violence to speak out and privileges certain victims of sexual assault, and was institutionalized with the enactment of Megan's Law. ${ }^{6}$ Examining the legal conceptualization of sex crime facilitates an understanding of how dominant sex and gender ideology is institutionalized.

\subsection{Research Questions}

The purpose of this research is to analyze Megan's Law as the result of the media's construction of a sex and gender discourse about sexual offenders. Discourse can be conceived as a culturally constituted means of producing and transmitting meanings as truth that defines human social relationships and identities (Foucault 1970). I will use critical discourse analysis to examine how media constructions of sexual offenders and victims acquire meaning in the Congressional debates of 104 H.R. 2137 (Megan's Law). Broadly, two research questions guide this project:

1. How are media discourses about sex offenders and victims constructed in the legislative debate about Megan's Law?

2. How do these media discourses about offenders and victims draw on sex and gender systems for meaning in the legislative debate about Megan's Law?

\footnotetext{
${ }^{6}$ Privileged forms of sexual violence constitute those that fit into the traditional sexual crime model, such as those perpetrated by the "sexual psychopath," those that are committed by strangers in public spaces, and those with young female victims and male perpetrators. Although nine out of ten victims of sexual assault are women (NCVS 2000), privileged victims fit a "good-girl" gender stereotype, whereby the victim has little to no sexual past, was not dressing promiscuously, nor drinking. Non-privileged forms of violence constitute those that fail to fit into the sexual crime model.
} 
My goal is to move beyond the notion that Megan's Law is simply legal recourse aimed at controlling and preventing sex crime. To focus solely on how this legislation treats sexual assault as a form of deviance obscures the important ways Megan's Law shapes and contributes to the existing sex-gender system - the parts of social life that oppress women, sexual minorities, or other individuals under certain terms. ${ }^{7}$ By examining how media discourses of sex and gender are embedded in the legislative debate, I hope to contribute to an understanding of how highprofile, yet statistically rare instances, frame the cultural understandings of sexual violence.

\section{LITERATURE REVIEW}

During the 1990s, a proliferation of new preventative state sex offender legislation followed a cluster of notorious child sexual assaults including Amber Hagerman (Amber Alert), Polly Klaas (Three-Strikes Legislation), and Megan Kanka (Megan’s Law) (Jenkins 1998). Systematically, these laws have toughened the punitive response to sexual offenders providing increased and mandatory sentencing, community notification, and potential lifetime confinement. These laws have also spawned for-profit notification systems and pop-psychology prevention tips. For example, on Dr. Phil's website, he provides a list of overly vague "common characteristics" for parents "worried their teen may be a sexual predator.", These include "(1) low self-esteem, (2) a sense of entitlement, (3) refusal to take responsibility for actions and blames others or circumstances for failures, (4) the need for power and control, and (5) deviant sexual attitudes and behaviors." While Dr. Phil's "tips" seem to describe normative teenage

\footnotetext{
${ }^{7}$ Gayle Rubin (1975) first coined the term "sex-gender" system in "The Traffic of Women: Notes on the 'Political Economy' of Sex." She prefers this term over patriarchy, as it does not indicate that oppression is inevitable in that domain, but rather, is the result of particular social relations that organize it.

${ }^{8}$ Accessed February 23, 2012 from http://www.drphil.com/articles/article/266.
} 
behavior, these concerns reflect a broader social anxiety over sexual predators that rely on the traditional notion of a sexual offender (meaning they are abnormal, psychopathic individuals).

The perpetrators of assault against Amber Hagerman, Polly Klaas, and Megan Kanka have been defined as sexual predators (Crawford \& Hundley 2012; Knaupp 2007; Coyne 2009). Though these instances were horrific tragedies, these high-profile crimes were, and remain, exceedingly rare (Benedict 1992). Traditionally, rape has been conceived rather narrowly, with Linda Williams's (1970) classic rape, involving attack by a stranger, garnering the most attention. At the time of William's piece, rape was one of the least reported violent crimes (Robin 1977). Thirty years later, an estimated $54 \%$ of sexual assault crimes remain unreported. ${ }^{9}$

These statistics seemingly contrast with the pervasive media images and political discussions of sexual predators (Stoltenberg 2009). ${ }^{10}$ If sexual assault is no longer hidden, then why does it continue to be one of the least reported violent crimes? Perhaps more importantly, how do our ideas about the offender and victim shape the cultural context of sexual assault? In this section, I will review an understanding of normative ideas of the sexual offender, providing: a brief history and theoretical background on its socially constructed nature; research on how the media actively frame sexual crimes; and feminist analyses of sex crimes law.

\subsection{The Social Construction of Sexual Scripts: "Normalcy" vs. "Deviancy"}

A framework for understanding "normal" and "deviant" sexual behavior is provided by Simon and Gagnon's (1987) work on "sexual scripts." They follow a social constructionist model that rejects the assumption of innate sex drives, and focuses on learned patterns of interactions, or "sexual scripts.". Employing symbolic interactionism, the meanings people

\footnotetext{
${ }^{9}$ 2006-2010 averages from the National Crime Victimization Survey (RAINN 2013).

${ }^{10}$ During the 1990 s, there were approximately 6,427 mentions of "sexual predator" in major U.S. newspaper headlines, leads, and subject terms. See Table 1 for an expansion of these statistics or Stoltenberg (2005) for a broader discussion of how rape is made an election issue.
} 
construct around sexuality shape individual behavior (Blumer 1969; Simon \& Gagnon 1987). Notably, meaning arises in the process of interaction, whereby individuals interpret and internalize social knowledge (Blumer 1969). Thus, individuals draw from larger cultural elements to develop a subjective understanding of sexuality. Simon and Gagnon (1974:19) assert, "scripts are involved in learning the meaning of internal states, organizing the sequences of specifically sexual acts, decoding novel situations, setting the limits on sexual responses, and linking meanings from non-sexual aspects of life to specifically sexually experience.” This concept of externalizing motive was also presented by C. Wright Mills (1940:904), who argues, "rather than fixed elements 'in' an individual, motives are the terms with which interpretation of conduct by social actor precedes." In this sense, sexual desire can be understood as an accepted vocabulary of erotic motives (Jackson 1995).

Sexual scripts allow individuals to organize their feelings and behavior, and allow them to interpret actions as sexually normal or deviant. An individual's idea of appropriate or inappropriate behaviors are shaped by gender beliefs, providing a framework through which sexuality is learned and an erotic self-identity is created (Tolman 2002; Banker, Kaestle \& Allen 2010). Ridgeway and Correll (2004) define gender beliefs as the cultural rules or instructions for enacting the social structure of difference and inequality that we understand to be gender. Perceived gender differences are particularly salient regarding sexual behavior, as men and women are believed to be most different sexually. This is evident in traditional sexual scripts, where men are characterized as the active pursuers of (women's) sexuality, while women are "naturally" the passive recipients of (men's) sexual advances (Bradshaw et al. 2010).

Linda Williams's (1970:460) “classic rape" script reflects normative notions of gender and sexuality, in which a stranger suddenly and violently attacks in a deserted, public place, after 
which the victim must provide both evidence of the attack and her active resistance. Permeating this narrative are the themes of overt violence, stranger-danger, and the assumed male aggressor/female victim dichotomy. Notably, the home is often not thought of as a location for sexual violence, unless the attacker as stranger enters by force. This particular rape script is accepted, because since the earliest conceptions of rape law dating back to the Hammurabi Code and the Bible, rape has been conceived as an external, public threat (Brownmiller 1975). Under these laws sexual assault was not directed as a crime against the woman, but towards her husband or father. For example, in Hebrew law, if a man raped a girl, he would be required to pay her father 50 silver shekels in compensation for what would have been her bride price (Brownmiller 1975). No compensation or concern existed for the poor woman, except for the mourning of her lost "honor," and no other conception of sexual assault was codified. Today, this treatment of the sexual offender as an external threat remains, and has subsequently, shaped the legal response to sexual assault.

\subsubsection{Constructing Deviant Behavior: A History of Selective Legislation}

Historically, our country's legal response to sexual deviancy has varied according to socially constructed ideas of normal and deviant sexual behavior. From the colonial era until the late 1880 s, sexuality was regulated with a vague set of morality codes, prohibiting fornication, adultery, bestiality, and homosexuality (Jenkins 1998). One of the earliest attempts at policing sexual behavior occurred through miscegenation laws (Pascoe 1996). Lemire (2002) analyzed historic novels, short stories, and political cartoons throughout the revolutionary and civil war periods to examine how same-race desire transformed into a biological imperative through media sensationalism. Fears of the sexually aggressive and deviant Black man led to a wave of 
lynchings in the name of "preserving" the safety and racial purity of white women (Meiners 2009). In research on the politicization of sexuality, Lemire (2002) found that sexual desire was socially constructed along the social identity of race, whereby interracial couplings were seen as deviant, abnormal, and the government legislated this practice.

Similarly, the political and media-driven framing of sexual behavior can also seen in Senator Joseph McCarthy's highly publicized and threatening characterization of homosexuals, in which he launched an investigation to "ferret them out," fearing their innate susceptibility to communism (Blount 2005). The characterization of homosexuals as dangerous and deviant has persisted. For example as late as 2010, Republican Senator Jim DeMint of South Carolina made comments advocating the government weed out gay teachers (Montopoli 2010). ${ }^{11}$ These examples serve to problematize the State's legislation of sexual behavior, exposing how notions of deviance and normalcy can be used to repress equality, (at times) protect perpetrators, and normalize violence (Meiners 2009). For example, interracial marriage was not legalized until 1967 with Loving v. State of Virginia, and as late as 1993, it was legal for a man to rape his wife in some states. ${ }^{12}$

\subsubsection{Constructing the Sexual Offender}

The construction of Linda Williams's classic rape began in the late 1880s, when American psychiatry and medicine developed "sexual perversion" (Jenkins 1998). Perversion is distinct from the colonial concept of sodomy, in that perversion persisted whether it was acted upon or not (Finckenauer 1982). Over the next 100 years, the medical model's "pervert"

\footnotetext{
${ }^{11}$ During the same speech, he also advocated the "weeding out" of sexually active, unmarried women.

${ }^{12}$ For example, until 1993, North Carolina law stated, "a person may not be prosecuted under this article if the victim is the person's legal spouse at the time of the commission of the alleged rape or sexual offence unless the parties are living separate and apart" (National Center for Victims of Crime 2004). See http://bjs.ojp.usdoj.gov/content/pub/pdf/apvsvc.pdf for more on spousal rape law.
} 
permeated dominant knowledge systems and became entrenched in ideas of evolution, industrial progress, and eugenics (Janus 2009; Zilney \& Zilney 2009). As early as 1886, German psychiatrist Krafft-Ebing informs readers that most rapists are degenerate, imbecilic men in Psychopathia Sexualis (Brownmiller 1975). In Sexual Aberrations, Sigmund Freud (1905) discusses sexual "perversions," which largely are largely characterized by homosexuality. At the time, homosexuality was blamed for a variety of crimes, most notably was child sexual abuse. During the 1930s, Iwan Bloch, founder of sexology, argued that sexual psychopathologies were innately biological and were correlated to socioeconomic level (Haeberle 1983). During the same time period, medical doctor Havelock Ellis wrote four volumes on human sexuality titled Studies in the Psychology of Sex, in which he characterizes those who commit sexual crimes as mentally ill (Ellis 1942).

These texts radically transformed the framing of sex crime, creating what Michel Foucault (1966) calls a new episteme, or means of assessing truth and knowledge. The development of perversion transformed the meaning of the sex offender, becoming a key characteristic of those who perpetrate it. This medical contribution is reflected in the Diagnostic and Statistical Manual of Mental Disorders IV (DSM-IV). Used by virtually all mental health professionals in diagnosing problematic behaviors, the DSM-IV contains more than 40 sexual behaviors considered to be psychiatric including bisexuality and transvestitism (APA 1994). Homosexuality was also included in the DSM-IV until heavy lobbying by the gay rights movement during the 1960 s and 1970 s succeeded in gaining its removal. ${ }^{13}$ The impact of a behavior being listed in the DSM-IV is immense. Foremost, the listing can dictate one's ability to obtain health insurance, and secure employment. Also, it can impact a person's ability to

\footnotetext{
${ }^{13}$ The removal of homosexuality from the DSM was a minor victory, as it was replaced with other sexual behaviors that are characterized as deviant and "disorders."
} 
retain parental rights, it can assign stigma, and threaten one's social status (Zilney and Zilney 2009).

In sum, the medical model's "pervert" internalizes sexual behavior and pathologizes the perpetrator. This reduces the cultural problem of sexual assault into a simple, individual personality flaw. A key function of "sexual scripts" is to define normal and deviant sexual behavior as distinct actions with little room for cross over. The construction of deviant sexuality has been achieved historically through legislation and medicalization. The perceived deviant sexual script of sex offenders has a monumental impact on how society views abuse, as it is no longer seen as a crime committed by an average person, but is an inherent sex drive belonging to a perverted predator.

\subsection{Cultural Studies: The Role of Media in Shaping Sexual Abuse Scripts}

Cultural studies is an interdisciplinary academic field, rooted in critical and Marxist theories that seeks to understand how socio-historical political forces shape contemporary social interaction (During 1993). Developed by British scholars in the 1950s, cultural studies rejects objectivism to study culture in relation to individual experiences. This focus on subjectivism is important to research on sexual abuse, as while there certainly are dominant discourses concerning sexual scripts, sexual abuse is something that happens to people, in a personal context, and has devastating consequences regardless of its statistical relevance. However, while providing a space for individual identity and experience, cultural studies facilitates an understanding of "conjunctural knowledge," meaning knowledge situated in political and historical circumstances, as well as, an awareness that the structure of representations, which 
form culture's alphabet and grammar, are instruments of social power, requiring critical and activist examination" (Hall 1993:97). ${ }^{14}$

With the advent of the pathologized pervert in the late 1800s (Jenkins 1998), sexual scripts of the sexual offender began to develop and take hold. In 1908, W. Travis Gibb, examining gynecologist at the New York Society for the Prevention of Cruelty of Children published an article on gonorrhea in children, suggesting there was "enormous and prevalent" child sexual abuse (Sacco 2009). ${ }^{15}$ Gibb cited perversion and ignorance as the cause of abuse, and his widely publicized article generated numerous police investigations and arrests.

Throughout his career, Gibb went on to research and catalog other forms of molestation, including an assault in which two men performed cunnilingus on an eleven-year-old girl. Gibb asserted these types of assaults were perpetrated by "men who are insane, old men beyond the age of virility, men under the influence of liquor, and those suffering from some form of perversion of the sexual instinct, which may be akin to insanity" (Jenkins 1998:30).

Criminologists and moral crusaders echoed Gibb's findings, which often correlated sexual abuse with poverty, poor education, and slum housing (Sacco 2009). Today, our concept of the sexual offender remains the pathologized "pervert," who is characterized as an uncontrollable sexual menace, a man beyond punishment or treatment, who requires the utmost imprisonment (Bourke 2007).

\subsubsection{Media Influence and Disseminating the Image of Sexual Abuse}

\footnotetext{
${ }^{14}$ Conjunctural knowledge was developed by Antonio Gramsci in the Prison Notebooks. See Perry Anderson's (1991) The Antinomies of Antonio Gramsci for a more detailed assessment of Gramsci's work.

${ }^{15}$ The NYSPCC was a charity formed in 1987 to investigate physical maltreatment and neglect of the young. By 1910 , over 300 "charity" imitators emerged across the country, and the organizations original goal of preventing cruelty, evolved into wider schemes for remodeling the family structures of the poor into replicating middle-class models (Jenkins 1998).
} 
Since Gibb's article in 1908, the media have become major providers of information about sexual abuse (Benedict 1992; Best 1993). Like family and peers, the media constitute a major socializing agent, exposing individuals to cultural scripts of gender, sexuality, and socioeconomic (Stinson 2010). In an analysis of media influence and public understandings of sexual violence, Jenny Kitzinger (2004) asserts that the media have become an influential medium in regard to agenda setting and the creation of new discursive repertoires. Also, through the process of reporting, news media produce and normalize cultural ideas about what is important, benign, and criminal. Though it is easy to condense the press into an overarching, vague, conglomerate, it is important to recognize that journalists are distinct and separate individuals. Despite this potential plurality, researchers have found consistent and dominant characteristics in how the media treat and shape our cultural understanding of the sex offender.

In Threatened Children, Joel Best (1990) employs a constructionist approach to analyze the media's role in claims-making- referring to the social process of making arguments. Examining the basis and process of how social problems are presented, he found the mass media to be especially important. As news media do not simply transmit messages, but translate and transform them, they are considered secondary claims-makers. These types of claims-makers are distinguished by their concerted efforts to persuade audiences. Also, Best analyzed the press's treatment of threats to children, and these themes' subsequent adoption into fiction, films, and popular culture. He found a positive relationship between the two media types and asserted that media play a central role in the acceptance of attempted media claims. Further, he asserts that when the press draws public attention to issues, policymakers are more responsive to news stories about a problem. Lastly, he asserts that media coverage in itself should not be taken for granted, meaning every topic is important, given the finite space and time in which a particular 
medium can cover a topic. Consequently, the press selects stories to publish or air based upon “novelty, drama, or other elements it values" (Best 1990:88).

The selection and framing of sex crime has a profound effect on its public reception. Helen Benedict's (1992) qualitative analysis of sex crime coverage during the 1980s and early 1990s found that media claims of sexual abuse were used to perpetuate myths and stereotypes about rape. Benedict found a decline in quality of accurate sex crime depictions. In particular, she observed that the press preferred to discuss crimes against white victims, and covered cases with distinct class and race prejudice by highlighting crimes with non-white, and lower class perpetrators. Benedict (1992:261) also found that the content of sex crime stories did not "inform the public of the reality of the crime [or] help people protect themselves." Rather, the press coverage of sex crimes was likely to feed fears, myths, and misconceptions, particularly in regard to a woman's sexual history and the race and class of the perpetrator. For example, journalists frequently criticized a woman's clothing, her whereabouts, and picked her version of the story apart. However, alleged perpetrators who were non-white and below middle class were more likely to be considered guilty by the press. Benedict asserts these gender and race biases are attributed to the lack of feminist perspective found in media coverage of sex crime. Rather than ignore gendered aspects of sexual assault, a feminist perspective would provide a focus on the power disparities inherent to sexualities, such as how men are trained, through socialization, to see women as objects of prey.

\subsubsection{Media Templates: Solidifying the Perverted Predator}

Given the media's heightened authority in shaping cultural discourses, accurately framing sex crime is of vital importance. In Perverts and Predators, Zilney and Zilney (2009) provide a 
genealogy of sex crime laws since the late 1800s. Focusing heavily on the medical model of the pervert, they trace the history of sex crime legislation and the media, arguing the only true way to deal with sexual violence is through sex-positive education and counseling. They argue that once the public sees something in the media, it becomes part of the public's image of the problem and may help justify new public policies.

While media may not dictate what viewers think, it informs what viewers think about. In Framing Abuse, Kitzinger (2004) examines the mass media's role in defining (and sometimes transforming) the issue of sexual abuse. Drawing on 20 years of research within media studies, Kitzinger (2004) focuses on how people "interpret, recall, relate to, and use media coverage in making sense of sexual abuse." She asserts that media templates, drawn from key events, such as a high profile case, are the primary frameworks used by news media to cover a particular topic. Kitzinger (2004) argues that media templates constitute a crucial site of cultural power, providing context for how society understands a social problem and informs social policy. In practice, these help (1) define public issues, (2) shape our understandings of particular cases, beliefs, and suspicions, and (3) inform how we think about each other and ourselves.

Importantly, media templates have routinely been found to focus on the serious but infrequent case (Benedict 1992; Bourke 2007; Jenkins 1998). They simplify details, provide minimal opportunities for alternative interpretation, and attach meaning to events by linking subsequent episodes (Benedict 1992; Kitzinger 2004). In effect, media templates the horrifically rare, and skews the realities of the problem. Statistics of sexual abuse reflect this concern.

According to the Centers for Disease Control and Prevention's (CDC) (1998) Prevalence, Incidence, and Consequences of Violence Against Women Survey, one out of every 6 American women has been the victim of an attempted or completed rape (14.8\% completed rape; $2.8 \%$ 
attempted rape), meaning 17.7 million American women have been victims of attempted or completed rape. Though all the major, personalized sex crime bills (Amber Alert, Three Strikes, and Megan's Law) concerns white victims, national statistics reflect that sexual abuse is pervasive across racial lines. In fact, rates of rape or attempted rape were found to be highest among American Indian/Alaskan women (34.1\%), mixed race women (24.4\%), and black women (18.8\%). Lastly, according to U.S. Bureau of Justice Statistics (2000), an overwhelming $93 \%$ of juvenile sexual assault victims know their attacker- approximately $34.2 \%$ of attackers were family members, $58.7 \%$ were acquaintances, and only $7 \%$ of perpetrators were strangers to the victims, placing the most common location of sexual assault squarely in private spaces. The statistics on sexual assault challenge the validity of popular media templates, and problematizes the extent to which legislative solutions have been based on these discourses.

Contemporary media templates about sexual abusers are very dramatic, characterizing perpetrators as perverted predators. Historian Philip Jenkins (1998) summarizes this image: The molester is a compulsive individual who frequently commits crimes and resists rehabilitation. Legions of abusers roam the country preying on hundreds or thousands of victims. In order to protect children and women, deviants must be identified, segregated, and routinely monitored. This discourse, drawn from the metaphoric language of tabloid crime writers is dramatic (Bourke 2007), however, it has increasingly become associated with any crimes of sexual violence or stalking, shaping the cultural view of the sexual predator. In Failure to Protect, Jenkins (1998) conducted a genealogy on the creation of social facts on sex crime, examining the social process of how victims and perpetrators are characterized. Paying particular attention to the meaning imbued in language, Jenkins (1998) traces the use of the terms put them each in quotation marks pervert, pedophile, molester, defiler, psychopath, and predator. Notably, he found 
characterizations of the sex criminal to be fluid, whereby "interpretations have sometimes favored a fairly benign model (the passive, rather pathetic figure of the 1960s), and at other times a model diametrically opposed to the first (the sex fiend of the 1950s or the serial pedophile of the 1990s)" (Jenkins 1998: 216). Also, he found the rise of the sex predator laws, such as Megan's Law, to resurrect the "old architecture" of sexual violence, undermining feminist reform beginning in the 1990s.

Cultural studies research provides a valuable basis for analyzing how the media shapes knowledge on sexual abuse. Drawing on the medical model, media templates frame a narrow, yet influential view of abuse particularly in regard to the sexual psychopath. This figure has become a stand-in for all perpetrators of abuse, despite its statistical irrelevance. When combined with Simon and Gagnon's (1974) sexual scripts, the sexual psychopath embodies a wholly deviant representation of sexual desire, and with the advent of the "sexual psychopath laws," this image was canonized in law. In the past 40 years, feminist anti-rape reformers sought to deconstruct this dominant image of the sex offender, to ground sexual assault in the realities of everyday life. The following section will provide a background of feminist law reform, and ground Megan's Law as a departure from legal advancements in gender equality.

\subsection{Feminist Analyses of Sex Crimes and Sex Crimes Law}

State regulation of sexual assault is a key site that defines the social facts about rape, discourses on who is dangerous, and how sexual assault should be eliminated. Critical feminist scholarship is grounded in women's experiences and is wholly committed to dismantling sex and gender inequality. Feminist legal scholarship (FLS) is centered on critical examination of the relationship between gender and law, giving particular attention to how that relationship might 
be improved (Bartlett 2012). To do this, FLS holds that political context and history are essential to understanding current situations (Estrich 1987). When FLS is applied to sex crime legislation, Megan's Law can be seen as unraveling advancements made in rape law reform. This section will provide a background of feminist advancements in law reform, paying specific attention to how sex crime laws can be viewed as an inaccurate and oppressive means of dealing with sex crime.

\subsubsection{Feminist Reformers: A Brief Period of Enlightenment}

An important period in FLS occurred from the 1970s to the 1990s, when the dominant legal understanding of sexual assault began to transform. As a social movement, feminist law reform had both instrumental and symbolic goals (Berger, Searles, \& Neuman 1995). Instrumentally, reform offered a tangible, mechanical means to create change, while symbolically, improving women's social status and legitimacy. The latter provided a vital prerequisite for social change as it transformed how women's problems were perceived by the State and legitimized feminist goals and values (Freeman 1975; Marsh, Geist, \& Caplan 1982). Rape reform was an important starting point, as feminists saw rape as a visible place to begin social change (Berger et al. 1995).

Until the 1970s, sex crimes were narrowly defined. Rather than more common forms, the type of sexual assault most recognized was the medical model's perverted sexual psychopath (Brownmiller 1975). Further, due to informal racism, assaults against non-white women and children were barely recognized by the State, and violence under certain circumstances, such as in marriage, was not considered assault at all. In fact, spouses were immune from prosecution 
based "on the assumption that when a woman married she impliedly and irrevocably consented to the sexual advances of her husband" (Berger et al. 1995:224).

Overall, sex crime law was not woman-centered, but took a skeptical stance against women's cries of sexual assault viewing them as untrustworthy (Berger et al. 1995). For example, Spohn and Horney (1992:24) cite that women were believed to lie about rape in order to "explain premarital intercourse, infidelity, pregnancy, or disease, or to retaliate against an exlover or some other man." During trials, women were often blamed for their attacks, particularly if they had been wearing provocative clothing, or had been drinking or flirting with men (Benedict 1992). As well, juries were warned that rape was easy to accuse, but difficult to disprove, and routinely, the victim's sexual history would be used to impeach her testimony. The ability of an attorney to use a victim's sexual history draws on socially constructed ideas of gender, in which "good girls" are to be desirable, yet not desiring (Reid, Elliott, and Webber 2011). Conversely, a sexually active woman can be discredited and blamed for her assault. In effect, the law functioned to regulate women's sexuality, while protecting male rights (Edwards 1981; Field 1983).

By focusing on the "classic rape," the law canonized the view that sexual assault was rare. More importantly, it required that the victim fit the model of traditional gender conformity, with no sexual past (Brownmiller 1975). To counteract these issues, rape law reformers sought to transform the image of assault and create a legal environment in which women's experiences with violence would be taken seriously. Foremost, feminists sought to advance the (empirically proven) fact that intimates and acquaintances perpetrate the most sexual violence (Bartlett 2012: Meloy, Saleh, and Wolff 2007). To do this, they sought to remove four instrumental barriers: (1) 
expand the concept of sexual assault, (2) abolish the victim requirement to "resist to the utmost," (3) abolish the "corroboration" requirement, and (4) enact rape shield laws (Janus 2000).

A key focus throughout the reform period was to redefine rape as "sexual assault" and "sexual battery." This allowed the concept of crime to expand beyond its traditional meaning, implying vaginal-penile intercourse, to include other types of penetration and touching (Berger et al. 1995). Importantly, redefining sexual assault expanded the scope of victims and offenders -the medical model lost its dominance. Also, the semantic change from "rape" to "assault" emphasized its nonconsensual aspects, exposing the power dimension of sexual violence, meaning that sexual violence is not solely a sexual act carried out by psychopathic men. Rather, assault also reflects an exertion of power. Feminist activist Susan Brownmiller summarizes this view with the assertion that, "Rape is an historical condition that underlies all aspects of malefemale relationships. It is a crime not of lust but of violence and power. The threat, use, and cultural acceptance of sexual force is a pervasive process of intimation that affects all women" (Moore 1975).

However, traditional gender and sexuality scripts were a major barrier to achieving true reform. Feminist scholar Catherine Mackinnon (1983:651-652) argues, "The distance between most sexual violations of women and the legally perfect rape measures the imposition of someone else's definition upon women's experiences. Rape from women's point of view, is not prohibited, it is regulated." MacKinnon implies that it is not the act of assault that is prohibited, but only the act under certain circumstances. Berger et al. (1995:230) summarizes the role of traditional gender scripts in rape laws arguing, "In a society where men are socialized to be the sexual aggressors, to expect women to be coy and reluctant, and even to dismiss women's protests, it is indeed difficult to distinguish acquiescence from freely given consent." 
Though feminist law reform has had a positive impact in terms of traumatizing victims less during the criminal justice process (Spohn \& Horney 1991), and Marsh et al. (1982) found a slight increase in arrest rates following reform, progress has stymied. Rape-law impact studies suggest that criminal justice officials continue to use the traditional framework of sexual assault and do not always comply with reformed statutes (Bienen 1980s; Marsh et al. 1982; Spohn and Horney 1992). Berger et al. (1995) found that local and state prosecutors prioritize the prosecution of "classic" rape cases, and that defense attorneys use legislative loopholes to use a victim's sexual history as discrediting testimony. The following section reviews how legal thought on sexual assault returned to the traditional medical model with the advent of the sex predator laws.

\subsubsection{Sexual Predator Laws: A Return to the Old Architecture}

Throughout the 1970s and 1980s, conservative opponents of rape law reform had little recourse to oppose reformation for fear of looking soft on crime (Zilney and Zilney 2009). Until the mid-1990s, challenges to feminist reform were interpreted as threatening to victims' rights (Janus 2000). However, the dominance of traditional views of assault returned with the advent of the sexual predator laws, following the deaths of Amber Hagerman (Amber Alert), Polly Klaas (Three Strikes Law), and Megan Kanka (Megan’s Law). By drawing on the concept of the sexual predator, old sexual violence assumptions were easily resurrected with these cases (Corrigan 2006). These cases revitalize the notion of stranger-danger, emphasizing the medical model of the sex offender, and diminish the role that community values play in understanding and controlling sexual violence (Janus 2000). In effect, stranger-danger provides a visible symbol of sexual violence and minimizes the roles that gender inequality and cultural values play in 
facilitating a culture of sexual assault (Bourke 2007; Janus 2000). Most importantly, strangerdanger allows sexual violence to be constructed in terms of individual personality flaws, rather than a social problem grounded in a culture of violence towards women.

Feminist legal scholar Rose Corrigan (2006) argues that our country's political response to sexual violence illuminates cultural values about sexuality, power, and social control. Megan's Law constitutes an important landmark and site of state regulation and supervision. However, it also represents an important site of gender norms, deviancy, power, and shapes the broader definition of sexual risk. By situating sexual assault in public spaces, Megan's Law provides the legal circumstances to create offenders, and then disembody them as predators. Also, the structural aspects of this legislation reveals how sexual assault is understood as a crime committed by perverted, sexual psychopaths who require special policing and surveillance.

To date, research on Megan's Law has focused largely on the effectiveness of sex crime policy and legislation (Levenson, Sandler, \& Freeman 2012; Duwe \& Donnay 2008; Veysey, Zgoba, \& Dalessandro 2008). Some critiques have explored Megan’s Law in more cultural context such as Jenkins (1998), who views the current focus on child sex abuse as simply another "moral panic" concerning sexual deviance. While these studies raise some important issues, they do not theoretically engage with how sexed and gendered media representations of sexual assault are permeated in the legislative process. Further, they fail to identify how sex crime discourse is produced and reproduced through media and legislation, particularly in terms of using sexual scripts, the concept of the perverted sexual psychopath, and the use of gender to develop an ideal victim. Megan's Law is an enduring institution in the scope of sex crime legislation. As a premier legislative institution, it has unique characteristics. However, it is important to recognize 
that these characteristics are not singular. The cultural values and assumption of Megan's Law extend beyond this legislation to replicate and influence other institutions.

As specified earlier, the research questions that drive this project are: (1) how are discourses about sex offenders and victims constructed in the legislative debate about Megan's Law? And (2) how do these media discourses about offenders and victims draw on sex and gender systems for meaning in the legislative debate about Megan's Law? To help analyze these questions in a critical feminist perspective, I will use the concepts of normative and deviant sexual scripts, including the "classic rape," and the medical model's construction of the sexual offender as a "sexual psychopath" as espoused through media templates.

\section{RESEARCH METHODOLOGY}

I use critical discourse analysis to examine how media constructions of sexual offenders and victims acquire meaning in the Congressional debates of 104 H.R. 2137 (Megan's Law). The topic of sex crime legislation intersects sociological concepts of state power and truth, and cultural ideas of gender and sexuality. Qualitative methods are preferred for interpreting how individuals and groups interact and attribute meaning to social experiences (Rapley 2007). An effective qualitative examination of the legislative debate on Megan's Law requires a methodology that can handle interpretative analysis, while dealing with the broader gender, sexuality, and power implications. Discourse analysis interprets the possible meanings of texts in terms of the multiple systems of power that shape their construction and distribution (Hoy 1999).

The form of discourse analysis I used is inspired by Foucault's conception of discourse. Discourse can be understood as a means of constructing and distributing meanings in a way that governs what we consider to be true about the social world and ourselves (Foucault 1970). 
Foucault and other poststructualist theorists did not propose a definitive methodology for analyzing discourses and in some instances are purposively ambiguous (Hoy 1999). This methodological fluidity is characteristic of discourse analysis, and the specific research procedures that encompass this approach vary widely (Perakyla 2005). Rather than a specific method, a discourse analysis methodology can be conceived as a particular approach to examining a research question. This approach allows the social and political conditions behind a particular social problem to be revealed, and by exposing these assumptions, facilitates a more comprehensive view of the problem (Hartsock 1990: Foucault 1970; Sawicki 1996; Hoy 1998; Seale 1998; Emerson, Fretz, \& Shaw 2011). The remainder of this section will detail the particular form of discourse analysis I used for this research.

I used a four-pronged coding process to identify discursive themes that appear in the legal records associated with 104 H.R. 2137, Megan's Law. During the initial reading, I coded for instances of direct media references, which included citations of high-profile sexual assault cases, general news reports on sex crimes, and references to media outlets themselves. Next, I reviewed and recoded these instances of direct media reference to document the context and clarify the meaning of the reference. When the full meaning of the speaker's media reference was not clear solely from the Congressional record, I located the specific newspaper reference in the LexisNexis or ProQuest databases. Next, I then re-read and recoded the documents to "parse overlapping concepts and to look for alternative readings of the data" (Weitz 2009:21). With this process, data were not simply recorded based on its particular characteristics, but interpreted within the broader social context in which it appeared. The legal records associated with 104 H.R. 2137, Megan's Law were read four times to confirm the speaker's intended message. This process was focused, including a fine-grained, line-by-line analysis. Lastly, when new references 
ceased to emerge, data were organized into a coding spreadsheet that documented the particular reference, its thematic content of either "sex offenders" or "victims," the speaker, the speaker's background, and my analysis and interpretation of the quote.

To ensure a rigorous and focused interpretation of the quotes, I posed a set of theoretically informed research questions that guided my analysis of discursive themes in the legal records associated with 104 H.R. 2137:

1. What gendered and sexed discourses about victims and offenders are being presented as truth or as the norm?

2. How are these gendered and sexed discourses about victims and offenders constructed?

a. What "evidence" is used to construct these discourses?

b. What alternative meanings are not included or ignored?

3. What interests are mobilized and served by presenting these gendered and sexed discourses as the truth?

I documented my analytical interpretation of these questions for each instance of direct media reference in the coding spreadsheet.

Paying attention to the authority and power of the speaker was an important step in my analysis. Statements about victims and offenders in the Congressional record are offered as fact, and speakers at the hearing are verbally recognized as having a particular authority on the subject of sex crime. Understanding who, and by what authority, speakers are able to make statements about sex offenders and victims in the political sphere helped to uncover how "knowledge" about sex crime is perpetuated and produced in the Congressional hearing. In most circumstances, the authority of the speaker was directly stated by Congressman Dick Zimmer of New Jersey, who is the author of Megan's Law, and frequently introduces speakers by mentioning either their experience on particular Congressional committees or their previous history dealing with the 
legislation of sex crime. For all Congressional speakers, I conducted brief political biographies, which are publicly available at the www.bioguide.congress.gov website. For the two nonpolitical speakers, I sourced biographical information through their respective non-profit organization websites and a LexisNexis search.

Although I identified specific meanings in the text, recognizing the absence of implicit discourses about sexual offenders and victims was also important. The identification of "what is missing" is characteristic of discourse analysis, as this contributes to a more contextual understanding of the meanings of a particular discourse (Charmaz 2010; Weiss 1994). Thus, I interpret the text for alternative meanings through identifying exclusions, erasures, and missing information in order to ensure saturation and a more holistic analysis (Rheinharz 1992). Within my coding speadsheet, I documented the absences of particular discourses alongside the speaker's explicit characteristics of sex offenders and victims.

Lastly, the purpose of this research is to analyze Megan's Law as the result of the media's construction of a sex and gender discourse about sexual offenders and victims. It is important to note that I am not analyzing the specific media discourses that speakers reference. Rather, I seek to examine how media constructions of sexual offenders and victims are invoked in the Congressional debates. Coverage of the Megan Kanka case was intense and pervasive in the time leading to the hearing. For example, a ProQuest newspaper search of "Megan Kanka" between the date of her death and the date of the hearing yields 897 results in print media alone, while a search of "sex crime" within the same period yields 1557 results. Consequently, I take the widespread coverage of the Kanka case as evidence of an accepted media template of sexual abuse for the purposes of this research. 


\section{DATA}

The data for this project come from (1) legal records associated with 104 H.R. 2137, Megan's Law, including reports, hearings, and congressional records and (2) historical media documents. Megan's Law passed through Congress quickly. It was first reported in the House on May 6, 1996, then heard and unanimously passed on May 7, 1996 and on May 8, 1996, passed in the Senate without debate. President Clinton enrolled the law on May 17, 1996. There are five congressional records associated with Megan's Law and a statement given by President Clinton as he signed the bill into law. These are (1) H.R.2137.RH (reported in house), (2) H.R. 2137.IH (introduced in house), (3) H.R. 2137.EH (passed in house), (4) H.R.2137.ENR (final as passed both house and senate), and (5) H.R. 2137.PCS (placed on Senate Calendar for vote). These records can be accessed at The Library of Congress THOMAS website (www.thomas.loc.gov), which documents and publishes the legislative history of Federal bills and resolutions.

To ensure these were all the relevant legal records associated with the passing of Megan's Law, I cross-searched government publications for "Megan's Law" and 104 H.R. 2137 on the U.S. Government Printing Office website (www.gpo.gov). The GPO publishes and disseminates services for the official and authentic government publications to Congress, Federal agencies, Federal depository libraries, and the American public. Though I analyze all six documents, the debate and hearing in the House of Representatives were of particular interest, as this contains the actual debate and bulk of discussion sex offenders and victims. The speed at which Megan's Law was enacted and its uncontested passage indicates that it was an uncontroversial bill. Yet, ample space and time were still dedicated to garnering support.

\section{FINDINGS}


In the Congressional hearing on Megan's Law, and within its associated documents, there is an overt reliance on media images of sex offenders and victims. For example, in Megan's Law Report 104-555 (p.2), submitted to the Committee of the Whole House on the State of the Union, Representative McCollum (FL) writes, "Perhaps no type of crime has received more attention in recent years than crimes against children involving sexual acts and violence. ${ }^{16}$ Several recent tragic cases have focused public attention and resulted in public demand that government take stronger actions against those who commit these crimes.” McCollum explicitly indicates that high-profile cases facilitated the development of the bill, and, as he later repeats this statement in his House testimony, his assertion foreshadows the Congressional use of media discourses to justify the passage of Megan's Law.

The bulk of testimony and discussion of victims and offenders occurs during the House hearing on May 6, 1996. These statements are expressed through a series of legislator speeches, which are overwhelmingly in support of the law. Given this favorable tone, the Congressional hearing reads as a sequence of individual, persuasive narratives, which implore the necessity of the bill. Almost uniformly, the speakers express similar, repetitive, and narrow themes. Speakers rely on the Kanka case, and a few similar high-profile cases, to construct a singular image of sexual violence, in which a child is victimized by a sexual predator. This narrative emerges through two key discourses: a focus on one type of child victim and the characterization of sex offenders as dehumanized predators. These themes construct sexual violence as an act committed against an innocent victim, at the hands of a pathologized psychopath, in a risky public space.

\footnotetext{
${ }^{16}$ Representative Bill McCollum is a republican House Representative who served in office from 1980-2001. He represented Florida's 5th Congressional District which stretches from Jacksonville to Orlando. From 1989-1995, he served as the Vice Chairman of the House Republican Conference- the 5th highest ranking position in the House Republican leadership. He took a leadership role in managing Bill Clinton's impeachment trial in the Senate, and from 2007-2011 he served as the Attorney General of Florida.
} 
This depiction of assault is the only type presented in the hearing, and in this research, I refer to this as the "Megan's Law rape narrative."

In itself, the Megan's Law rape narrative is easy to condemn. The facts of the case are clear, and there is limited room for alternative interpretations of the assault. In this sense, the Megan's Law rape narrative is reminiscent of Linda Williams's "classic rape," replacing the adult female with the child victim. Key traits of the "classic rape" victim are a feminine innocence, purity, and absence of a sexual past outside of marriage. Children not only embody the innocence and purity required of the "classic rape" victim, but as childhood is seen as an asexual time, children are viewed as inappropriate targets and agents of sexual desire.

Consequently, child victims generate universal outrage and as a normal person is seen as capable of assaulting a child, the offender is framed as a maniac.

In the Megan's Law rape narrative, the offender is constructed as a pathologized male. The ultimate pervert, he is characterized as an uncontrollable sexual menace, a man beyond punishment or treatment, requiring the utmost imprisonment. Speakers at the hearing rely on the fear induced by infamous, repeat sexual predators of children, characterizing their behavior as the norm. Single instance offenders do not exist in the Megan's Law rape narrative, and are instead, replaced by the escalating threat of kidnap or murder. Like the "classic rape," the Megan's Law rape narrative supports the falsehood that threats of abuse typically arise in public spaces at the hands of stranger-maniacs.

\subsection{Focus on Specific Types of Child Victims}

In the debate, media discourses about sexual abuse victims are directly invoked by legislators and speakers cite the Kanka case as evidence of a sexual violence problem against 
children. For example, Representative Dunn (H4456-57) asserts, “The tragic and highly publicized 1994 rape and murder of 7-year-old Megan Kanka in New Jersey . . . unfortunately became the impetus for including sexual predator language in the 1994 crime bill." ${ }^{, 17}$ In this statement, Dunn not only recognizes the Kanka case as an important abuse narrative, but by noting its "highly publicized" nature, he alludes to its authority and salience in the public sphere. The intense coverage of Megan Kanka's case allowed her rape/murder to function as an accessible narrative to communicate, understand, and regulate sexual abuse. Consequently, Megan Kanka is not just any victim; she is the archetypal victim.

The age of the Kanka archetypal victim is used by speakers to elevate their victim status. For example, Representative McCollum (FL) (H4452) asserts that children are "the most vulnerable" and the "most defenseless citizens." ${ }^{18}$ Similarly, Representative Schumer (NY) (H4453) states "children are the most vulnerable members of our society," and Representative Frelinghuysen (NJ) (H4455) asserts, “as parents we constantly worry about the well-being of our children because we know of their innocence and vulnerability." Drawing in the issue of abuse, Representative Upton (MS) (H4456) argues, “There is no greater crime, I do not believe, than a child that has been molested, perhaps killed, or not killed, but sexually molested by somebody else." The themes of vulnerability and innocence expressed by speakers parallel the normative notions of conventional gender and sexuality, whereby women and children are given a protected status. However as victims, this childhood innocence not only refers to their naivety, but also

\footnotetext{
${ }^{17}$ The 1994 crime bill refers to the Violent Crime Control and Law Enforcement Act, which contained a title, the "Jacob Wetterling Crimes Against Children and Sexually Violent Offender Registration Act," named after a child who had been missing for several years. That title encouraged States to require "every person who commits a sexual or kidnapping crime against children, or who commits sexually violent crimes against any person, whether adult or child, to register his address with the State. ${ }^{18}$ Representative Bill McCollum is a republican House Representative that served in office from 1980-2001. He represented Florida's 5th Congressional District which stretches from Jacksonville to Orlando. From 1989-1995, he served as the Vice Chairman of the House Republican Conference- the 5th highest ranking position in the House Republican leadership. He took a leadership role in managing Bill Clinton's impeachment trial in the Senate, and from 2007-2011 he served as the Attorney General of Florida.
} 
their asexuality. This is expressed in Representative Upton's statement that victimization of a child constitutes "no greater crime."

Speakers at the hearing repeatedly invoke the Kanka archetypal victim to demonstrate need for the law. From simply mentioning the name "Megan Kanka," to succinctly communicating the facts of her assault, speakers affirm, at times redundantly, the cultural salience of her case:

We have brought forth this bill in the name of, tragically, Megan Kanka, who was raped and strangled and murdered by a twice-convicted pedophile who lived across the street from her. Representative Jackson-Lee (TX) (H4454)

I rise today in support of Megan's Law, a bill named in honor of 7-year-old Megan Kanka who was raped, strangled, and murdered by a twice convicted pedophile who lived across the street from her. Representative Jackson-Lee (TX) (H4454)

It is a sad note that it took the tragedy of Megan Kanka's abduction and murder to make America aware of the need for this legislation. Representative Frelinguysen (NJ) (H4455)

In late July 1994, a young 7-year old girl named Megan Kanka was sexually assaulted and brutally murdered by at twice-convicted sex offender who lived across the street...The entire community, Mr. Speaker was absolutely stunned and horrified. Representative Smith (NJ) (H4453)

On July 29, 1994, a beautiful little girl named Megan Kanka was lured into the home of a man who literally lived across the street from her. He said that he had a puppy he wanted to show her. He then proceeded to brutally rape and murder this little girl. It was later found that the man who is accused of killing little Megan Kanka was twice convicted of being a sexual predator. He lived with two housemates who were 
themselves convicted sexual predators, and no one in the neighborhood was aware of it. Representative Dick Zimmer (NJ) (H4452)

I still find it tragic beyond words, Mr. Speaker, that no one knew that Megan Kanka's killer lived across the street. No one know that the murderer was a two-time convicted sex offender who was released from prison in 1988 after spending 6 years of a 10 year sentence. No one knew that he lived with two other men who had previous records of sex crimes. Representative Smith (NJ) (H4453)

It is not surprising that Megan's death would be referenced in her namesake bill. High profile cases function as an accessible narrative for legislators to understand and describe sexual assault. Consequently, cases that mimic the Kanka archetype are elevated in importance because they legitimate the relevance of her case. Legislators draw on these in the debate. For example,

This particular bill, for example, it will protect children like Monique Miller of Houston, TX, who was brutally murdered and sexually abused by a repeat offender. ${ }^{19}$ Representative Jackson-Lee (TX) (H4455)

Last year I had two little boys, sons of migrant workers from Texas, in my district who were stolen allegedly by a sexual molester, because he has not been convicted yet I use the word allegedly, out from Iowa, picked them up in the twin cities in Michigan; and thank goodness, because it was a nationwide case and CNN and ABC News and "Good Morning America" had his picture, they found him in New Orleans. I do not want that to happen again to that family. Representative Upton (TX) (H4456)

Throughout the hearing, these are the only other victims discussed, and these not only match the Kanka archetype, but were also cases that garnered local and national media attention. By only

\footnotetext{
${ }^{19}$ Demetrius Simms was convicted in the abduction and murder of 3-year-old Monique Miller. Simms lured the young girl from a city housing complex to a wooded area where he raped, strangled, and then bludgeoned the child to death with a tree branch. Three days later, Simms was caught while attempting to abduct another child. Though his lawyer claimed mental defect, the motion to remove the death penalty was denied. Garnering media attention, the story of Monique Miller and subsequent trial appeared in newspapers and on television in 1996.
} 
discussing victims who are similar to Megan Kanka, the presentation of sexual assault in the hearing is extremely narrow. Even in the hypothetical, legislators invoke the Kanka archetypal victim. For example, Representative Molinari (NY) (H4457) asks:

For those that oppose the bill, I would like you to envision the loss of your child. I ask you to feel the loss of your child to a ruthless criminal, who saw her as nothing more than an easy victim. I ask you to stand in the place of Maureen Kanka, the mother of 7-year- old Megan Kanka, who was kidnapped and murdered by a man who had twice been convicted of attacking children.

At times, speakers use the Kanka archetypal victim narrative in conjunction with macrolevel statistics. While this strategy is used to humanize victims, these instances conflate the prevalence of sexual abuse with the existence of one particular type of victim. Appearing alongside "objective" sex crime authorities and statistics, the authority of the Kanka archetypal victim is heightened. For example, Representative Jackson-Lee (TX) (H4455) states:

There is growing recognition that most sex offense victims are children and that reporting of these offenses are still low. The FBI law enforcement bulletin reported that only 1 to 10 percent of children or child molestation cases are ever reported to the police. According to Children's Trust Fund of Texas, in 1995, 50,746 children, ages birth through 17 , were victims of child abuse and neglect . . . So I am here to applaud the author this legislation ... This is an important step, Mr. Speaker, to stop the victimization of our children ... I want to see a stop now and forever to senseless violence that has seen children even being kidnapped from their bedrooms and violently and sexually abused.

Jackson-Lee (H4455) then repeats a second time that, "This particular bill [will] protect children like Monique Miller of Houston, TX who was brutally murdered and sexually abused by a repeat offender." This not only has the effect of transposing high-profile victim discourse onto all child 
abuse victims, but by reiterating the case of Monique Miller, she indicates that Monique's narrative, like Megan's, is common. The distinction between victim types is further blurred when Jackson-Lee juxtaposes broader issues of sexual abuse, such as low reporting, with circumstances uniquely attached to Kanka archetypal victims, such as the "senseless violence that has seen children even being kidnapped from their bedrooms and violently and sexually abused."

Using a similar juxtaposition strategy, Megan’s mother, Maureen Kanka (HA133), implores:

On July 29, 1994, our seven year old daughter Megan was lured into the home of a man that lived across the street from our house. He raped, strangled, murdered then dumped her body in a nearby park as if she were a piece of trash. After her body was found, we discovered that our neighbor was a twice convicted pedophile . . . It has been very difficult dealing with the loss of our daughter Megan . . . Every day, children across our country are raped and murdered. I see at least two reports daily on the news of children that were sexually abused. Unfortunately, when a pedophile is caught and apprehended, he will only serve a minimal sentence. In many cases, through plea bargaining, you would never know he sexually assaulted a child anyway ... Thus the need for mandatory community notification across this country.

As one of two non-legislative speakers in the hearing, ${ }^{20}$ Maureen Kanka is seen as an authority on victimhood. ${ }^{21}$ Like Jackson-Lee, as Maureen Kanka juxtaposes Megan's death against other victims in the news, she professes the prevalence of the Kanka archetype. Further, by invoking the pronoun "he," Maureen Kanka asserts that offenders are male, and advances the gendered

\footnotetext{
${ }^{20}$ The second non-legislative speaker is Ernie Allen of the National Center for Missing and Exploited Children.

${ }^{21}$ Legislators openly applaud Maureen Kanka for her bravery and contribution to the law. For example, Representative Smith (NJ) (H4454) states "Despite the fact that they were overcome with indescribably grief and pain, Megan's heroic parents, Maureen and Richard, mounted a full court press. . Megan's courageous parents had an absolute right to know of this."
} 
construction of sex offenders. Further, as she asserts offenders are likely to have multiple convictions, she invokes the predator discourse, in which recidivism is paramount.

In a similar instance, Ernie Allen, ${ }^{22}$ President and CEO of the National Center for

Missing and Exploited Children (NCMEC), asserts that child abuse is on the rise. Allen (H4453) states that on April 14, 1992, the New York Times "reported that one in six prisoners in state and federal prisons were sex offenders" and that, "sex offenders are growing second in number only to drug offenses.. ${ }^{23} 24 \mathrm{He}$ also argues:

Megan's tragic and untimely death helped millions of Americans understand several key facts: (1) that most of the victims of sex offenders in the United States are children and youth; and (2) that a significant number of offenders have a high propensity to reoffend. Therefore, we need to take simple, basic steps to alert communities (H4453).

Like Representative Jackson-Lee and Maureen Kanka, Allen combines statistics and media discourses to assert the Megan's Law rape narrative is a normative and looming sexual threat. However, by focusing solely on one type of high-profile victim, the prevalence of more common sex crimes are ignored. For example, according to U.S. Bureau of Justice Statistics (2000), assault by acquaintances account for $58.7 \%$ of reported sex crimes and assault by a family member accounts for $34.2 \%$ of reported sex crimes. Further, the existence of older victims is completely ignored save for Jackson-Lee's acknowledgement: "We recently honored Victims

\footnotetext{
${ }^{22}$ Ernie Allen is an attorney who served as President and CEO of the NCMEC for 23 years until he retired in 2012. Allen is an active spokesman on child sexual abuse and regularly appears on network and cable news shows including, NBC, CBS, ABC, CNN, FOX, Oprah, and Larry King. See http://www.missingkids.com/en US/documents/ErnieAllenBio.pdf for a brief biography of Allen.

${ }^{23}$ The NCMEC is a non-profit organization founded in 1984 by a Congressional Authorization and works in partnership with the U.S. Department of Justice. The organization was launched in response to two high-profile missing children cases, including the disappearance and murder of 6 year old Adam Walsh. After the disappearance, Adam's father, John Walsh became an advocate and activist and serves on the board of NCMEC. In 1988 Walsh secured a deal with FOX to host the television show America's Most Wanted.

${ }^{24}$ Although Allen cites the article as evidence of a growing problem of sexual offenders, the article "New Therapies Help Sex Offenders Learn How Not to Repeat Sex Crimes," actually advocates for innovative therapies for sex offenders that will help them "control the cycle of troubling emotions, distorted thinking, and deviant sex fantasies that lead to their sex crimes" (C1). See http://ezproxy.gsu.edu/login?url=http://search.proquest.com/docview/108986858?accountid=11226 for the full article.
} 
Rights Week to pay tribute to all of the young women and children in this country whose lives have been cut short by hideous acts of violence. ${ }^{, 25}$ However, rather than address more common assault types, Representative Jackson-Lee's focus remains on young victims who suffer assault under the most rare and extreme circumstances- those that end in death.

The intense coverage of Megan Kanka's assault allowed her case to function as an accessible media template. In the legislative debate, speakers invoke this media template by repeating the Megan's Law rape narrative, and at times, conflate the existence of child rape/murders with aggregate statistics of sex crime. The Kanka archetypal victim presented in the debate, draws on conventional notions of gender and sexuality, in which victims exhibit both feminine innocence and asexuality. However, by focusing solely on one type of victim, the diverse circumstances in which abuse occurs is ignored.

\subsection{Sexual Psychopath Rhetoric}

In the Megan's Law rape narrative, the offender is constructed as a pathologized male. Whereas the dominant feature of victims is their young age, the primary characteristic of the offender is his innate and deviant sexuality. As the victim in the Megan's Law rape narrative embodies a feminine ideal, the offender symbolizes a broken masculinity, which is exhibited through his assumed inability to engage in appropriate sexual behavior and propensity to recidivate. Speakers characterize the offender as an outsider, a maniacal predator, and the ultimate sexual threat. Similar to the narrow presentation of victims, the discussion of offenders

\footnotetext{
${ }^{25}$ National Crime Victims Week is an annual commemoration that promotes victims' rights and services. It was established in 1981 by President Ronald Reagan as part of a program to provide for victims of crimes. It is sponsored by the Office for Victims of Crime, an arm of the U.S. Department of Justice.
} 
relies on a limited number of high-profile media cases that mimic Jesse Timmendequas's profile, producing the Timmendequas predator narrative.

Before abusing Megan Kanka, Jesse Timmendequas was convicted twice for the sexual assault of young girls. During coverage of the Kanka case, reporters paid particular attention to Timmendequas's history of sexual abuse and violence. ${ }^{26}$ In fact, media coverage of his past was so widespread that Timmendequas appealed his guilty verdict to the New Jersey Supreme Court, arguing the jury's knowledge of his prior convictions swayed their opinion (161 N.J. 515, 737 A.2d 55, p13). Although the court ruled the jury had not been tainted, the issue of recidivism came to define Timmendequas. ${ }^{27}$ As discussed earlier, whenever Megan Kanka is mentioned, Timmendequas's history of abuse is also stated. Further, however, the phrase "twice convicted" or "repeat offender" is always used when discussing victims during the hearing, making recidivism a defining characteristic of offender discourse. For example, Representative Zimmer (NJ) (H4452) states:

On July 29, 1994, a beautiful little girl named Megan Kanka was lured into the home of a man who literally lived across the street from her ... It was later found that the man who is accused of killing little Megan Kanka was twice convicted of being a sexual predator. He lived with two housemates who were themselves convicted sexual predators, and no one was aware of it.

Later, Maureen Kanka states, "My daughter would be alive today if I had known that my neighbor was a twice-convicted pedophile.” By externalizing offenders, the speakers situate the source of abuse in public, rather than private spaces and by focusing on the repetition and

\footnotetext{
${ }^{26}$ A ProQuest Newspaper search of the terms "Megan Kanka" and "twice-convicted," from the date of Megan's death to the date of the Congressional hearing results in 302 results.

${ }^{27}$ The New Jersey Supreme Court response indicates, "While jurors admitted to knowing or suspecting that Timmendequas had a prior record of sex offenses. The trail court subjected potential jurors to painstaking questioning, and repeatedly instructed them that the verdict and sentence were to be based solely on the evidence presented at trial. Allowing jurors to sit despite their knowledge or suspicion of Timmendequas's prior record was not [a] reversible error" (161 N.J. 515, 737 A.2d 55, p13).
} 
perversion of the offender, the Timmendequas predator narrative is affirmed. For example, Representative Upton (MS) (H4456) states:

I had a woman in my district talk to me in tears about her 9-year-old that was raped. Thank goodness he was convicted. He is now serving in Jackson Prison. But he is going to get out. The experts say that he is going to do it again and again and again ... When he gets out ... he is going to have a tattoo on his head that is going to be there forever.

In these instances, Zimmer, Upton, and Kanka indicate that recidivism is not only a defining characteristic of abusers, but also, frame them as external, public threats, as if simply knowing who they are would have prevented abuse. The importance of identifying offenders is captured in Representative Upton's reference to a "tattoo," which refers to the community notification aspect of Megan's Law. As the sexuality of offenders is considered dangerous and unchangeable, the law, in function, literally seeks to identify and (presumably segregate) offenders from the general population. The act of public marking dehumanizes offenders and affirms their abnormal sexuality and lesser masculinity. This discourse is summarized in the Congressional findings published in the enrolled bill on May 11, 1996, that state:

1. There exists a small but extremely dangerous group of sexually violent persons who do not have a mental disease or defect;

2. Persons who are sexually violent predators generally have antisocial personality features that

a. Are not amenable to mental illness treatment modalities in existence on the date of enactment of this Act; and

b. Render the persons likely to engage in sexually violent behavior; 3. The likelihood that sexually violent predators will repeat acts of predatory sexual violence is high; and

4. The prognosis for curing sexually violent predators is poor and the treatment needs of the population of the predators are very long-term. 
The dehumanization of offenders continues throughout the hearing, as speakers characterize them as men of "unspeakable danger and perversion,",28 with "toxic lives.,"29 Speakers depict hypothetical offenders with anonymous or vague personas and succinctly refer to them as "predators." In each instance, the threat of recidivism is transposed onto all offenders, and particular attention is paid to the abusers' sexuality that separates them from normal, average citizens. Consequently, abuse is constructed as the result of individual personality flaws, rather than grounded in cultural issues of control, power, or gender inequality. For example, Representative Schumer (NY) (H4453) asserts:

Sex offenders are different . . . even after long, long years in prison and many, many attempts to rehabilitate, when these folks come out of prison, the odds are extremely high that they will commit the same or a similar crime again. Long prison terms do not deter them. All too often, special rehabilitation programs do not cure them. No matter what we do. The minute they get back on the street, many of them resume their hunt for victims, beginning a restless and unrelenting prowl for children, innocent children to molest, abuse, and in the worst cases to kill.

Described as animalistic, with wily and insatiable sexual desires, sexual offenders are viewed as the lowest members in society. For example, Representative Molinari (NY) (H4457) states, "The fact that [Timmendequas] was released and allowed to roam the streets in and around young children, is nothing less than placing a wolf among lambs.” Representatives Schumer and Molinari explicate the "non-human" sexuality embodied with Timmendequas onto all offenders by focusing on the deviancy of Timmendequas's sexuality.

\footnotetext{
${ }^{28}$ Representative Smith (NJ) (H4454)

${ }^{29}$ Representative Cunningham CA (H4454). At the time of the hearing, Representative Cunningham was the chairman of the Early Childhood Youth and Family Subcommittee.
} 
Speakers affirm the salience of the Timmendequas predator narrative in the single other instance an offender is personified. In this case, Representative Cunningham (CA) (H4454) relies on a similar high-profile case when he asks, "Can [you] imagine Larry McQuay? Would [you] want that individual to move in next door to [your] family without knowing about it?" Like Timmendequas, McQuay aligns with the Timmendequas predator narrative. One month before the debate, McQuay garnered massive media attention when he requested surgical castration in order to prevent him from molesting children again. ${ }^{30}$ In 1990, McQuay was forced to resign his bus-driving job when he was reported for trying to persuade a 13-year-old boy to have sex with him. After word of the incident spread to McQuay's girlfriend, she discovered McQuay had forced her six-year-old son to have oral sex with him numerous times. McQuay was paroled in 1993 on good behavior, but was incarcerated seven months later for writing to then-governor Ann Richards, demanding he be castrated to prevent him from molesting again. After returning to prison he discussed his other molestations, and claimed to have victimized over 240 children. McQuay's request for castration drew overwhelming media interest, and one month prior to the debate on Megan's law, he conducted numerous interviews, including those with Oprah Winfrey, NBC's "Dateline," ABC's "Good Morning America," and the "Donahue” show (Shlacter 1996). The McQuay interview aired on Oprah's "ChildAlert," the name of a series of shows concerning child sexual abuse (Hinckley 2011). "ChildAlert" was organized around the tragic stories of several abused children, who as a result of their abuse, subsequently suffered either abortion, parental rejection, or an insatiable need to buy pornography (Longino 1996). Herself a childhood victim of rape, Oprah labels offenders "evil on this planet" and told viewers to "contact politicians and demand change in the judicial handling of child sexual abuse cases"

\footnotetext{
${ }^{30}$ Due to his request, in 1997, Texas passed a law permitting inmates to voluntarily have surgical castration. However, surgical castration has not been found to prevent abuse and sexual abuse can occur through means other than the penis.

${ }^{31}$ In the mid-1990s averaged 12.6 million viewers per show (Hinckley 2011).
} 
(Longino 1996). Referring to this effort, Representative Schroeder (MI) (H4454) gives direct thanks to Oprah Winfrey for her "help with this act."

As with Timmendequas, the predator narrative personified through Larry McQuay further characterizes the sexual offender as a compulsive monster, exhibiting a deviant male sex drive. Legislators warn that, "The danger of recidivism in sex crimes has been demonstrated, time and time again," and this looming threat marks offenders as people not only incapable of having appropriate sexual relationships, but also incapable of reform. ${ }^{32}$ The distinction between offenders and normal people is furthered by Representative Jackson-Lee (TX) (H4454-55) when she asserts that, "This bill [identifies] individuals with this inclination. . .and members of the family, parents, school officials, community groups, neighbors. . .all of us. . .who are innocent." Jackson-Lee (TX) not only expresses the recidivism theme, but by listing "innocent" individuals in the community, she externalizes offenders as distinct from normative community members. Similarly, Representative Schroeder (MI) (H4454) states, “This is what [Megan's Law] is about: watching, watching [convicted] people or things that might harm the children, and watching the children to make sure they cannot get in harm's way themselves.” Further, Representative Schumer (NY) (H4453) states, "We should be warning communities in which these predators live. Parents, teachers, [and] neighbors have a right to protect themselves and their children from the violent acts of these proven offenders." Jackson-Lee, Schroeder, and Schumer's assertions support the Timmendequas predator narrative, in which offenders are viewed as different and simply identifying those previously convicted will separate the innocent from the guilty.

Speakers at the hearing support this view by reiterating the threat of "stranger danger." For example, Representative Dunn (WA) (H4457) asks, "Wouldn't you and your family like to know when a potential predator has moved in next door so that adequate steps could be taken to

\footnotetext{
${ }^{32}$ Representative Molinari (H4457)
} 
protect your family?" Ignoring the prevalence of family assault, other legislators frame parents as those most capable of providing protection. Applauding the success of local notification in one California community, Representative Lofgren (CA) (HA101) asserts,

"We have established a hotline for parents to call. . .we also have books with names [and pictures] of people who parents ought to be alerted to. . you have to provide some justification [to see], but it is not a very high standard. . .if you say, I am a parent, that is good enough."

While certainly most parents do not abuse their children, when offenders are portrayed as easily distinguishable individuals, the public notification goal of Megan's Law is positioned as a simple solution to prevent abuse.

Operationally, Megan's Law functions under a three-tiered system, whereby each tier correlates with increasing penalties and registration requirements. ${ }^{33}$ Tier 1 offenders must update their whereabouts every year for 15 years; Tier 2 offenders must update their whereabouts every six months for 25 years; and Tier 3 offenders must update their whereabouts every three months with lifetime registration. The general guidelines for classification under Megan's Law is listed in Table 1. Once a person is convicted of a sexual crime, assignment into the tiers is done with the Registrant Risk Assessment Scale Manual (RRASM), which ranks offenders as "low risk," “moderate risk," and "high risk" for a series of criteria. ${ }^{34}$

\begin{tabular}{|l|l|l|}
\hline \multicolumn{3}{|c|}{ Table 1: Sex Offender Guidelines for Classification and Notification Under Megan's Law } \\
\hline \multicolumn{1}{|c|}{ Tier I } & \multicolumn{1}{|c|}{ Tier II } & \multicolumn{1}{|c|}{ Tier III } \\
\hline $\begin{array}{l}\text { Misdemeanor registration offenses, } \\
\text { child pornography possession, and } \\
\text { any other sex offenses that do not } \\
\text { support a higher classification. }\end{array}$ & $\begin{array}{l}\text { Felonious sexual abuse or sexual } \\
\text { exploitation crimes involving victims } \\
\text { who are minors, including } \\
\text { distribution and producing child } \\
\text { pornography. }\end{array}$ & $\begin{array}{l}\text { Forcible sexual assaults regardless of } \\
\text { the victim's age, sexual contact } \\
\text { offenses against children younger } \\
\text { than age 13, and non-parental } \\
\text { kidnapping of minors. }\end{array}$ \\
\hline
\end{tabular}

\footnotetext{
${ }^{33}$ The tiered system is commonly called SORNA (Sex Offender Registration and Notification Act), and was enacted as The Adam Walsh Child Protection and Safety Act. SORNA was named for Adam Walsh, the six-year-old victim whose death also led the government creation of the National Center for Missing and Exploited Children.

${ }^{34}$ A copy of the RRASM is available in the Appendix. See http://www.state.nj.us/lps/dcj/megan1.pdf for further explanation of the ranking criteria.
} 
The Timmendequas predator narrative presented in the debate carries over to the functional aspects of Megan's Law. For example, the RRASM criteria "victim selection" is related to the likelihood of re-offending. Notably, interfamilial offenses, such as abuses against siblings, biological children, and stepchildren, are described as "low risk," while abuses against a neighbor's child, a child one is babysitting, or date rape are described as "moderate risk," and the sexual abuse of a stranger is described as "high risk." Reflecting the privileging of the Kanka archetypal victim and the Timmendequas predator narrative in the legislative debate, instances of "stranger danger" are elevated in importance.

The salience of the predator narrative embodied through Timmendequas and McQuay is evident throughout the debate. Public knowledge of these men's actions occurred through nationwide media coverage, with particular attention paid to their repeat offenses. In the hearings, the threat of recidivism and the offender's deviant sexuality are frequently invoked. Even when speakers use more anonymous terms such as "sexual predator," the "abnormal" sexuality and lesser masculinity assigned to these men permeates the characterization.

\subsection{Discourse Homogeneity Through Disconfirming Evidence}

Throughout my analysis, I actively sought to uncover instances of disconfirming evidence and alternative portrayals of sex offenders and victims. As noted earlier, speakers at the hearing express similar and repetitive themes. In fact, the only partially dissenting voice in the set of documents I analyzed comes from Representative Watt (NC) (H4456). However, rather than dispute the victim and offender discourses presented throughout the debate, he grounds his dissent in questions of Constitutionality. He states: 
This is a tremendously difficult issue. I started to stay in my office and punt, and not come over here and talk about it at all. It is difficult because the statistics do indicate that there is a higher rate of recidivism for those people who have committed one offense in this area, and a greater likelihood that some will commit another offense.

However, I thought it would be a dereliction of my duty as a Member of this body not to point out two very troubling aspects about this bill. First of all, our Constitution says to us that a criminal defendant is presumed innocent until he or she is proven guilty. The underlying assumption of this bill is that once you have committed one crime of this kind, you are presumed guilty for the rest of your life. That, Mr. Speaker, is contrary to the constitutional mandates that govern our Nation. We should not be presuming people guilty unless they have committed a crime. Once they have paid their debt to society, they should be allowed to go on with their lives.

The second concern I have about this issue is that my colleagues in this body have over and over talked to us about how important States rights are. Yet in this area, somehow or another we cannot seem to justify allowing States to make their own decisions about whether they want a Megan's Law or do not want a Megan's Law. All of a sudden, the Big Brother Government must direct the States to do something that is not even necessarily a Federal issue.

Though Representative Watt (NC) speaks out against Megan's Law, he does not contest the actual discourses about victims and offenders presented in the hearing. Further, he does not submit alternative portrayals of sex crime or mention the diverse circumstances under which abuse can occur. In fact, Watt (NC) (H4456) draws on the Timmendequas predator narrative to assert "there is a higher rate of recidivism for those people who have committed one offense in this area.” As Watt's opposition to Megan's Law lies in terms of its Constitutionality, he 
provides no dissenting alternatives to the discourses invoked, and ultimately, when it comes to the House vote, Watt recuses himself, casting neither a 'yay' or 'nay' vote. ${ }^{35}$

Watt's testimony comes towards the end of the hearing, and the few legislators who speak after him respond directly to his remarks imploring the necessity of the bill. Representative McCollum (FL) (H4456) asserts:

Contrary to what some have said about it earlier, this is not a mandate on the States . . This is to encourage the States to do things that we think they need to do as a group to fight such types of crimes as we have in the case of those who commit violence against children, especially sexual crimes, by holding the carrot out of money that they may receive of Federal largesse that they otherwise would not receive. ${ }^{36}$

Similarly, Representative Ramstad (MN) (H4456) states that, "National tracking [is] needed because of the propensity of these offenders to repeat their heinous crimes again and again after their release from prison." Ramstad (H4457) draws on the predator discourse to implore:

Wouldn't you and your family like to know when a potential predator has moved in next door so that adequate steps could be taken to protect your family? American women and families deserve no less. Every time we hear of a crime committed by a sexual predator . . . Our daily routine is monopolized by tension and anxiety: waking to our cars, sending our children off to school, or locking up the house at night ... We can and must pass a law that will require notifying a community when a sexually violent predator has moved into the neighborhood.

\footnotetext{
${ }^{35}$ After Megan's Law passage, numerous appeals were made asserting that the law was unconstitutional on grounds of violating the Double Jeopardy and Ex Post Facto clauses of the Constitution. These were ultimately struck down when a Federal appeals court ruled the intention of community notification is to protect, rather than punish the offender, and is thus, not punitive. See http://www.jcil.org/journal/articles/226.html for more information on the Constitutionality of Megan's Law.

${ }^{36}$ Megan's Law coerces States to abide by the notification requirement by providing a financial incentive for States to establish effective registration systems for released child molesters and other sexually violent offenders. States that fail to establish systems are subject to a 10 percent reduction in Byrne Grant funding, the resulting surplus is reallocated to complying States. The Edward Byrne Memorial State Grant is awarded through the U.S. Dept. of Justice. This program was created by the Anti-Drug Abuse Act of 1988. The intent of this formula grant program is to provide funds to assist State and local units of government in carrying out specific programs that offer a high probability of improving the functioning of the criminal justice system, and to enhance drug control efforts.
} 
Within the legislative debate on Megan's Law, I found no alternative images to the Kanka archetypal victim and Timmendequas predator narratives. In fact, in the single instance of dissension, Representative Watt affirms the recidivism discourse. With no disconfirming evidence, the legislators' reliance on high-profile media cases produces a narrow and homogenous construction of assault. In the hearing's concluding speech, Representative Molinari (H4457) invokes both victim and offender discourses to once again frame offenders as predators, and repeat the Megan's Law rape narrative:

Critics of this bill have argued that the bill unduly punishes offenders after they have paid their debt to society. What about the void and pain of the parents whose son or daughter became their victim? When are they finished paying? For those who oppose the bill, I ask you to envision the loss of your child. I ask you to feel the loss of your child to a ruthless criminal, who saw her as nothing more than an easy victim. I ask you to stand in the place of Maureen Kanka, the mother of 7-year-old Megan Kanka, who was kidnapped and murdered by a man who had twice been convicted of attacking children ... The danger of recidivism in sex crimes has been demonstrated, time and time again, unfortunately at the expense of another child.

\section{DISCUSSION}

This research examined (1) how media discourses about sex offenders and victims were constructed in the legislative debate about Megan's Law, and (2) how these discourses draw on sex and gender systems for meaning. The debate narrowly focused on one type of sexual assault, in which an "innocent" child is abused by a sexual psychopath. Legislators invoke media images of high-profile cases as providing both evidence of a sex crime problem and a framework for defining victims and offenders. The salience of high-profile cases is asserted in multiple instances, however, it is most clear when Representative McCollum (FL) (H4452) states 
"Several recent tragic cases have focused public attention and demand that government take stronger action against those who commit these crimes." While speakers repeatedly reference high-profile cases, no attention is given as to why certain assault cases become high-profile and certain cases do not. Media coverage of cases should not be taken for granted, given the finite space and time in which a particular medium can cover a topic- as, the press selects stories based upon "novelty, drama, or other elements it values" (Best 1990:88).

Previous research on media templates found they simplify details, provide minimal opportunities for alternative interpretation, and attach meaning to events by linking subsequent episodes (Benedict 1992; Kitzinger 2004). Though Megan Kanka's case was certainly shocking, the rape and murder of a young child does not constitute the average assault. However, the range of circumstances in which abuse can occur is never addressed. In the debate, discussion of adult victims or violence perpetrated by acquaintances and family are clearly absent, and no dissenting voice or alternative images of assault emerges. Conversely, cases with victims similar to Megan Kanka and offenders similar to Jesse Timmendequas are used by speakers to legitimize the Kanka case. Consequently, the Megan's Law rape narrative comes to define sexual assault in the hearing, providing minimal opportunities for alternative interpretation.

As legislators focus on the child victimization by stranger narrative embodied with the Kanka case, the fact that many sex crimes are perpetrated against adult women is obscured. ${ }^{37}$ Thus, rather than an act grounded in a sex/gender system that affords people different power and agency, sexual assault becomes defined as an act uniquely perpetrated by "evil" sexual predators. Accordingly, these high stakes offenders require the high stakes consequences offered by Megan's Law. Registry, community notification, and surveillance are designed to stigmatize sex crime convicts, and perpetuate the view that private spaces are safe, and public spaces are

\footnotetext{
${ }^{37}$ One of every 6 American women has been the victim of an attempted or completed rape (CDC 1998).
} 
dangerous. However, increasing penalties undoes feminist efforts to ground sexual assault as a cultural problem that frequently occurs within intimate relationships, in private spaces. Further, the act of marking and segregating offenders perpetuates the falsehood that committing a sex crime is something unique, innate, and the problem of a small, but dangerous, group of men.

Reminiscent of Linda Williams's “classic rape," the facts of abuse, as presented in the debate, are clear and framed within traditional notions of gender and sexuality. As speakers rely solely on the child victimization by predator narrative embodied with the Kanka case, sexual violence is situated as an act committed against an "innocent" victim, at the hands of a pathologized psychopath. Key traits of the "classic rape" victim are a feminine innocence and purity. Children not only embody these requirements, but as children are considered non-sexual beings, their sexual assault generates social outrage and automatically frames the offender as a sexual psychopath. Constructed as a male, with a deviant sexuality, the offender embodies an abnormal masculinity. This abnormal masculinity becomes the defining characteristic of the offender, making his deviant sexuality his "master status."

Beliefs about gender are particularly salient regarding sexual behavior (Hamilton and Armstrong 2009). This is seen in traditional sexual scripts, where men are characterized as the active pursuers of (women's) sexuality, while women are "naturally" the passive recipients of (men's) sexual advances (Bradshaw et al. 2010). In this script, normal men embody a male sex drive that links hegemonic masculinity to sexual prowess. As presented in the debate, sexual offenders do not possess a "normal" sexuality, but rather a misdirected, dehumanized, and predatory sex drive. "Normal" men are not seen capable of possessing the wholly deviant sexuality required to abuse an innocent child. Thus, pathology, rather than the roles that gender inequality and cultural values can play in facilitating sexual assault, becomes the defining 
characteristic of an offender. Notably, this allows sexual violence to be constructed in terms of individual personality flaws, rather than a social problem grounded in issues of gender inequality, power, control, or a broader culture of violence.

\section{CONCLUSION}

In the Congressional hearing on Megan's Law, and within its associated documents, there is an overt reliance on high-profile media images of sex offenders and victims to construct a singular image of sexual violence, whereby a child is victimized by a sexual predator. In terms of public support, it would certainly be difficult to find a situation more universally reviled than a sex crime against a child. However, in the debate, discussion of adult victims or violence perpetrated by acquaintances and family are clearly absent. The narrow focus on particular types of victims and offenders, facilitates a return to the conservative architecture of sex crime, in which there is a focus on "stranger danger" and risky public spaces, which dominated prior to feminist reform. Historically, sex crime has been underreported and legislators recognize this issue in the debate. In the debate, the offender's abnormal masculinity is considered unchangeable, and serves to justify the community notification aspect of Megan's Law. However, rather than prevent abuse, the high stakes consequences of registration and notification enacted with Megan's Law may make some victims, particularly those abused by a friend or relative, reluctant to come forward. Consequently, rather than prevent abuse, Megan's Law may only expose certain types of sex crime, and further obscure diverse forms of abuse. As the images of sex offenders and victims are constructed so narrowly, there is little room for discussion of this issue, or of alternative solutions that may address wider forms of abuse to emerge. 
To date, research on Megan's Law has focused largely on either its Constitutional legality or the effectiveness of community registration in preventing assault. This project addresses a gap in the literature, by examining how media discourses about victims and offenders permeate the legislative debate. The data for this research came from a single legislative case study. Future research should contextualize these findings in other legislative texts on sex crime, such as the Jacob Wetterling Crimes Against Children and Sexually Violent Offender Registration Act or The Adam Walsh Protection Act. Also, future research should examine the tools used to classify offenders, and compare these programs to those of the 1970s and 1980s, as this would provide greater insight into evolution or permanence of offender and victims discourses.

Every act of sexual violence, no matter how statistically insignificant, matters. It matters to the victim, and shapes our cultural understanding of sexual assault. Sex crime legislation can reveal our cultural values concerning sexuality, power, and social control. State regulation of assault helps to define our understanding of rape, and constitute what we view as dangerous spaces and dangerous people. Most importantly, perhaps, this helps illuminate how high-profile, yet statistically rare instances of assault, come to embody the cultural image of assault. 


\section{REFERENCES}

Arrigo, B. A. 2002. The critical perspectives in psychological jurisprudence: Theoretical advances and epistemological assumptions. International Journal of Law and Psychiatry 25:151-172.

American Psychiatric Association. 1994. Diagnostic and Statistical Manual of Mental Disorders. Washington, DC: Author.

Armstrong, D. 1983. Political anatomy of the body: Medical knowledge in Britain in the twentieth century. Cambridge, UK: Cambridge University Press.

Banker, J. E., Kaestle, C. E., and Allen, K. R. (2010). Dating is Hard Work: A Narrative Approach to Understanding Sexual and Romantic Relationships in Young Adulthood. Contemporary Family Therapy, 32, 173-191.

Bartlett, K. T. 2012. Feminist Legal Scholarship: A history through the lens of the California Law Review. California Law Review 100:380-430.

Benedict, H. 1992. Virgin or Vamp: How the press covers sex crimes. New York: Oxford University Press.

Berger, R.J., Searles, P., and W. L. Neuman. 1995. "Rape-Law Reform: Its Nature, Origins, and Impact." In Patricia Searles and Ronald J. Berger (eds.), Rape \& Society: Readings on the Problem of Sexual Assault. Boulder, CO: Westview Press.

Best, J. 1990. Threatened Children: Rhetoric and Concern about Child-Victims. Chicago: University of Chicago Press.

Bienen, L. 1980. “Rape III- National Developments in Rape Reform Legislation.” Women's Rights Law Reporter, 6:170-213.

Blount, J. 2005. Fit to Teach: Same-sex desire, gender, and school work in the twentieth century. New York: SUNY Press.

Blumer, H. 1969. Symbolic Interactionism: Perspective and Method. Berkeley, CA: University of California Press.

Bourke, J. 2007. Rape: Sex Violence History. Berkeley, CA: Counterpoint Press.

Bradshaw, C., Kahn, A. S., and Saville, B. K. (2010). To Hook-Up or Date: Which Gender Benefits? Sex Roles, 62, 661-669. 
Brownmiller, Susan. 1975. Against our will: Men, women, and rape. New York: Fawcett Books.

Cataldi, B.J. 2004. Foucault's Discourse Theory and Methodology: An application to art education policy discourse 1970-2000. Dissertation Ohio State University.

Charmaz, K. 2010. Grounded Theory in the $21^{\text {st }}$ Century. In The Sage Handbook of Qualitative Research, $3^{\text {rd }}$ Ed. Norman K. Denizin and Yvonna S. Lincoln (Eds). Thousand Oaks, CA: SAGE Publications.

Chenier, E. 2003. The criminal sexual psychopath in Canada: Sex, psychiatry, and the law at mid-century. Canadian Bulletin of Medical History 20(1), 75-101.

Crawford, S. and W. Hundley. 2012. "15 Years Later, Arlington Police Still Struggling to Solve Amber Hagerman Case. www.dallasnews.com, January 12, 2011. Retrieved February 24, 2012 from http://www.dallasnews.com/news/communitynews/arlington/headlines/20110112-15-years-later-arlington-police-still-struggling-tosolve-amber-hagerman-case.ece.

Corrigan, R. 2006. Making Meaning of Megan's Law. Law and Social Inquiry 31(2):267-312. Coyne, K. 2009. "For Megan's Dad, A Way to Make an Impact, Again.” www.nytimes.com, March 12, 2009. Retrieved February 24, 2013 from http://www.nytimes.com/2009/03/15/nyregion/newjersey/15colnj.html?ref=megankanka\& $\mathrm{r}=0$.

Dean, M. 1994. Critical and Effective Histories: Foucault's Methods and Historical Sociology. New York: Routledge

Denno, D. 1998. Life before the modern sex offender statutes. Northwestern University Law Review 92:1317-87.

During, S. 1993. Introduction in Simon During (ed.) The Cultural Studies Reader, $3^{\text {rd }}$ Edition. New York: Routledge.

Duwe, G., \& Donnay, W. (2008). The Impact of Megan's Law on Sex Offender Recidivism: The Minnesota Experience. Criminology, 46(2), 411-446.

Edwards, S. 1981. Female Sexuality and the Law. Oxford: Martin Robertson. 
Ellis, H. 1942. Studies in the psychology of sex: Volumes I, II, III, IV. New York: Random House.

Emerson, R., Fretz, R., and Shaw, L. 1995. Writing ethnographic fieldnotes. Chicago: University of Chicago Press.

Estrich, S. 1987. Real Rape: How the legal system victimizes women who say no. Cambridge, England: Harvard University Press.

Fairclough, N. 1995. Media discourse. London: Edward Arnold.

Fariclough, N. 1992. Critical Discourse Analysis: The Critical Study of Language. London: Longman.

Fairclough, N. 1989. Language and power. London: Longman.

Finckenauer, J. O. 1982. Scared Straight! And the Panacea Phenomenon. Englewood Cliffs, N.J.: Prentice-Hall.

Field, M. 1983. "Rape: Legal Aspects.” In S. Kadish (ed.), Encyclopedia of Crime and Justice, Volume 4. New York: Free Press.

Foucault, M. 1995. The Archeology of Knowledge. London: Routledge.

Foucault, M. 1966. The Order of Things: An Archeology of the Human Sciences. London: Routledge.

Freeman, J. 1995. The Politics of Women's Liberation. New York: David McKay.

Frug, M J. 1992. A Postmodern Feminist Legal Manifesto (An unfinished draft). Harvard Law Review 105.

Graber, D. A. 1984. Processing the News: How people tame the information tide. New York: Longman.

Gutting, Gary. 2008. "Michel Foucault", The Stanford Encyclopedia of Philosophy (Fall 2012

Edition), Edward N. Zalta (ed.), Retrieved February 28, 2013 from http://plato.stanford.edu/archives/fall2012/entries/foucault/.

Hacking, I. 1999. “The Archaeology of Foucault.” In Foucault: A Critical Reader, edited by David Couzens Hoy. Oxford: Blackwell Publishers.

Haeberle, E. J. (1983). Introduction in The Birth of Sexology: A Brief History in Documents. Washington, DC: World Congress of Sexology. www.indiana.edu/ Kinsey/resources/sexology.html (not paginated). 
Hall, S. 1980. “Encoding/Decoding.” Pp. 128-138 in Culture, Media, Language edited by S. Hall, D. Hobson, A. Lowe, and P. Willis. London: Hutchison.

Hall, S. 1993. "Cultural Studies and its Theoretical Legacies.” Introduction in Simon During (ed.) The Cultural Studies Reader, $3^{\text {rd }}$ Edition. New York: Routledge.

Hartsock, N. 1983. Money, Sex, and Power: Toward a Feminist Historical Materialism. Boston: Northeastern University Press.

Hartsock, N. 1990.’Foucault on Power: A theory for women?" In Feminism/Postmodernism ed. Linda Nicholson. London: Routledge.

Hinckley, D. 2011. Oprah Winfrey’s Final Episode Drew Her the Highest Ratings Since a 1994 Episode About 'Shedding.' Retrieved May 132013 from http://www.nydailynews.com/entertainment/tv-movies/oprah-winfrey-final-episodedrew-highest-ratings-1994-episode-shedding-article-1.147737.

Hoover, J. E. 1947. How safe is your daughter? American Magazine, 144 (July 1947), 32.

Hoy, D. C. 1999. "Introduction.” In Foucault: A Critical Reader, edited by David Couzens Hoy. Oxford: Blackwell Publishers.

Hoy, D. C. 1998. "Foucault and Critical Theory.” In The Later Foucault ed. Jeremy Moss. London: Sage.

Jackson, S. 1995. The Social Context of Rape: Sexual Scripts and Motivation. In Patricia Searles and Ronald J. Berger (Eds.), Rape and Society: Raedings on the Problem of Sexual Assault. Boulder, CO: Westview Press.

Janus, E. S. 2000. Sexual predator commitment laws: Lessons for law and the behavioral sciences. Behavioral Science and the Law 18(1)-5-21.

Jenkins, P. 1998. Moral Panic: Changing Concepts of the Child Molester in Modern America. London: Yale University Press.

Johnson Jr., A M. 1991. The New Voice of Color. The Yale Law Journal 100(7):2007-2063.

Karpman, B. 1954. The sexual offender and his offenses: Etiology, pathology, psychodynamics, and treatment. New York: Julian Press.

Kitzinger, J. 2004. Framing Abuse: Media influence and public understanding of sexual violence against children. Longon: Pluto Press. 
Knaupp, C. 2007. “Polly Klaas' Dad: 'Everything Changed' After Daughter's Death.” www.tylerpaper.com, April 26, 2007. Retrieved February 24, 2013 from http://www.tylerpaper.com/apps/pbcs.dll/article?AID=/20070426/NEWS07/70426013 .

Lawrence III, C.R., Matsuda, MJ, Delgado, R, and K. W. Crenshaw. 1993. "Introduction.” In M.J. Matsuda, C.R. Lawrence III, R. Delgado, \& K. Crenshaw (eds.) Words that wound: Critical Race Theory, assaultive speech, and the first amendment. Boulder, CO: Westview Press.

Lemire, Elise. 2002. "Miscengenation": Making race in America. Philadelphia: University of Pennsylvania Press.

Levenson, J. S., D'Amora D. A., and A. L. Hern. 2007. Megan's Law and its impact on community re-entry for sex offenders. Behavioral Sciences and the Law. 25(4): 587-602.

Levenson, J. S., Sandler, J. C., \& Freeman, N. J. (2012). Failure-to-register laws and public safety: An examination of risk factors and sex offense recidivism. Law And Human Behavior, 36(6), 555-565.

MacKinnon, C. 1983. Feminism, Marxism, method, and the state: Towards Feminist Jurisprudence. Signs 7:515-544.

MacKinnon, C. 1991. Reflections on sex equality under the law. The Yale Law Journal 100(5):1281-1328.

Marsh, J., A. Geist, and N. Caplan. 1982. Rape and the Limits of Law Reform. Boston: Auburn House.

McLarin, K. J. 1994. Trenton races to pass bills on sex abuse. The New York Times, August 30, 1994.

McVicker, S. 1995. The Trouble With Larry. Retreived May 272013 from http://www.houstonpress.com/1995-08-24/news/the-trouble-with-larry/.

'MEGAN'S LAW' Clinton Signs Bill on Sexual Predators Dole Praises Measure, GOP Lawmaker's Efforts."1996. Milwaukee Journal Sentinel, May 18, (http://ezproxy.gsu.edu/login?url=http://search.proquest.com/docview/260395209?accou $\underline{\text { ntid }=11226) \text {. }}$

Megan Nicole Kanka Foundation. 2012. Megan's Law The Right to Know. Megan Nicole Kanka Foundation. Website accessed February 23, 2012. 
Meiners, E. R. Never Innocent: Feminist trouble with sex offender registries and protection in a prison nation. Feminism, Race, and Transnationalism 9(2):31-62.

Meloy, M. L. Saleh, Y., and N. Wolff. 2007. Sex Offender Laws in America: Can panic-driven legislation ever create safer societies? Criminal Justice Studies 20(4): 423-443.

Mills, C. W. 1940. "Situated Actions and Vocabularies of Motives." American Sociological Review, 5:439-52.

Montopoli, B. 2010. Jim DeMint Criticized Over Comments on Gay and Sexually Active Teachers. Retrieved February 24, 2013 from http:/www.cbsnews.com/8301503544 162-20018607-503544.html.

Moore, S. 1975. Rape is a Crime of Lust, Not of Power, Argues Susan Brownmiller. Retrieved February 28, 2013 from http://www.people.com/people/archive/article/0,20065841,00.html .

National Center for Victims of Crime. 2004. Spousal rape laws: 20 years later. Retrieved February 232013 from http://www.ncvc.org/ncvc/main.aspx?dbName=DocumentViewer\&DocumentI $\mathrm{D}=3270 \mathrm{O}$.

National Institute of Justice \& Centers for Disease Control \& Prevention. 1998. Prevalence, Incidence, and Consequences of Violence Against Women Survey. Retrieved February 24, 2013 from

Pascoe, P. 1996. "Miscegenation Law, Court Cases, and Ideologies of "Race" in TwentiethCentury America." The Journal of American History 81: 1 44-69.

Perakyla, A. 2005. Analyzing Talk and Text. In The Sage Handbook of Qualitative Research. $3^{\text {rd }}$ Edition, edited by Norman K. Denzin and Yvonna S. Lincoln. Thousand Oaks, CA: Sage University Press.

Perkins, C. A. 2000. Age Patterns of Victims of Serious Violent Crime. Bureau of Justice Statisics: Special Report.

RAINN. 2013. http://www.rainn.org/get-information/statistics/sexual-assault-victims .

Rapley, T. 2007. Doing Conversation, Discourse, and Document Analysis. Thousand Oaks, CA: Sage Publications.

Reid, J. A., Elliott, S., and Webber, G. R. (2011). Hookups to Formal Dates: Refining the Boundaries of the Sexual Double Standard. Gender and Society, 25, 545.

Rheinharz, S. 1992. Feminist Methods in Social Research. New York: Oxford Press 
Rhode, D.L. 1991. The "no-problem” problem: Feminist challenges and cultural change. The Yale Law Journal 100(6): 1731-1793.

Ridgeway, C. L. and Correll, S. J. (2004). Unpacking the Gender System: A Theoretical Perspective on Gender Beliefs and Social Relations. Gender and Society, 18, 510-31.

Robertson, S. 2006. Crimes Against Children: Sexual Violence and Legal Culture in New York City. The University of North Carolina Press: New York.

Robin, G. 1977. Forcible Rape: Institutionalized Sexism in the criminal justice system. Crime and Delinquency, 23(2):136-153.

Rorty, R. 1999. Foucault and Epistemology. In Foucault: A Critical Reader, edited by David Couzens Hoy. Oxford: Blackwell Publishers.

Rubin, G. 1975. The Traffic in Women: Notes on the 'Political Economy' of Sex. Toward an Anthropology of Woman. Ed. Rayna Reiter. New York: Monthly Review Press, 1975. 157-185, 198-200.

Sacco, L. 2009. Unspeakable: Father-Daughter Incest in American History. Baltimore, MD: The Johns Hopkins University Press.

Sawicki, J. 1991. Disciplining Foucault: Feminism, Power, and the Body (Thinking Gender). New York: Routledge.

Sawicki, J. 1996. "Feminism, Foucault, and the 'Subjects' of Power and Freedom." In Feminist Interpretations of Foucault ed. Susan Hekman. Pennsylvania: Pennsylvania Press.

Seale, C. 1998. Constructing death: The sociology of dying and bereavement. Cambridge: Cambridge University Press.

Simon, W. and Gagnon, J. H. (1987). Sexual Scripts: Permanence and Change. Archives of Sexual Behavior, 15, 97-120.

Singleton, R. A. and B. Straits. 2010. Approaches to Social Research. New York: Oxford University Press.

Snyder, H. N. 2000. Sexual Assault of Young Children as Reported to Law Enforcement: Victim, Incident, and Offender Characteristics. National Center for Juvenile Justice.

Spohn, C., and J. Horney. 1991. "The Law's the Law, But Fair is Fair: Rape Shield Laws and Officials’ Assessment of Sexual History Evidence." Criminology, 29:137-60.

Spohn, C., and J. Horney. 1992. Rape Law Reform: A Grassroots Revolution and Its Impact. New York: Plenum. 
Stinson, R. D. 2010. "Hooking-Up in Young Adulthood: A Review of Factors Influencing the Sexual Behavior of College Students." Journal of College Student Psychotherapy 24:98115.

Stoltenberg, J. 2005. In Emilie Buchwald, Pamela R. Fletcher, Martha Roth (Eds.) Transforming a Rape Culture. Minneapolis, MN: Milkweed Editions.

Tainio, L. 2002. Negotiating gender identities and sexual agency in elderly couples' talk. In P. McIlvenny (ed.), Talking gender and sexuality. Amsterdam, Netherlands: John Benjamins.

Veysey, B. M., Zgoba, K., \& Dalessandro, M. (2008). A PRELIMINARY STEP TOWARDS EVALUATING THE IMPACT OF MEGAN'S LAW: A TREND ANALYSIS OF SEXUAL OFFENSES IN NEW JERSEY FROM 1985 TO 2005. Justice Research \& Policy, 10(2), 1-18.

Weiss, R. S. 1994. Learning From Strangers: The Art and Method of Qualitative Interview Studies. New York: The Free Press.

Weitz, R. 2010. "Changing the Scripts: Midlife Women's Sexuality in Contemporary U.S. Film." Sexuality and Culture 14:17-32.

Williams, L. 1984. The Classic Rape: When do Victims Report? Social Problems 31:459-67.

Wodak, R. 2001. The discourse-historical approach. In R. Wodak and M. Meyer (eds.) Methods of Critical Discourse Analysis. London: Sage.

Zilney, L. J., and L.A. Zilney. 2009. Perverts and Predators: The Making of Sexual Offending Laws. Lanham, MD: Rowman and Littlefield Publishers. 


\section{APPENDIX}

\section{Static-99R Coding Form}

\begin{tabular}{|c|c|c|c|c|}
\hline $\begin{array}{l}\text { Question } \\
\text { Number }\end{array}$ & Risk Factor & \multicolumn{2}{|c|}{ Codes } & Score \\
\hline 1 & Age at release & \multicolumn{2}{|c|}{$\begin{array}{l}\text { Aged } 18 \text { to } 34.9 \\
\text { Aged } 35 \text { to } 39.9 \\
\text { Aged } 40 \text { to } 59.9 \\
\text { Aged } 60 \text { or older }\end{array}$} & $\begin{array}{l}1 \\
0 \\
-1 \\
-3\end{array}$ \\
\hline 2 & Ever Lived With & \multicolumn{2}{|c|}{$\begin{array}{l}\text { Ever lived with lover for at least } \\
\text { two years? } \\
\text { Yes } \\
\text { No }\end{array}$} & $\begin{array}{l}0 \\
1\end{array}$ \\
\hline 3 & $\begin{array}{l}\text { Index non-sexual violence - } \\
\text { Any Convictions }\end{array}$ & \multicolumn{2}{|l|}{$\begin{array}{l}\text { No } \\
\text { Yes }\end{array}$} & $\begin{array}{l}0 \\
1\end{array}$ \\
\hline 4 & $\begin{array}{l}\text { Prior non-sexual violence - } \\
\text { Any Convictions }\end{array}$ & \multicolumn{2}{|l|}{$\begin{array}{l}\text { No } \\
\text { Yes }\end{array}$} & $\begin{array}{l}0 \\
1\end{array}$ \\
\hline 5 & Prior Sex Offences & $\begin{array}{l}\text { Charges } \\
0 \\
1,2 \\
3-5 \\
6+\end{array}$ & $\begin{array}{l}\text { Convictions } \\
0 \\
1 \\
2,3 \\
4+\end{array}$ & $\begin{array}{l}0 \\
1 \\
2 \\
3\end{array}$ \\
\hline 6 & $\begin{array}{l}\text { Prior sentencing dates } \\
\text { (excluding index) }\end{array}$ & \multicolumn{2}{|c|}{$\begin{array}{l}3 \text { or less } \\
4 \text { or more }\end{array}$} & $\begin{array}{l}0 \\
1\end{array}$ \\
\hline 7 & $\begin{array}{l}\text { Any convictions for non-contact sex } \\
\text { offences }\end{array}$ & \multicolumn{2}{|l|}{$\begin{array}{l}\text { No } \\
\text { Yes }\end{array}$} & $\begin{array}{l}0 \\
1\end{array}$ \\
\hline 8 & Any Unrelated Victims & \multicolumn{2}{|l|}{$\begin{array}{l}\text { No } \\
\text { Yes }\end{array}$} & $\begin{array}{l}0 \\
1\end{array}$ \\
\hline 9 & Any Stranger Victims & \multicolumn{2}{|l|}{$\begin{array}{l}\text { No } \\
\text { Yes }\end{array}$} & $\begin{array}{l}0 \\
1\end{array}$ \\
\hline 10 & Any Male Victims & \multicolumn{2}{|l|}{$\begin{array}{l}\text { No } \\
\text { Yes }\end{array}$} & $\begin{array}{l}0 \\
1\end{array}$ \\
\hline & Total Score & \multicolumn{2}{|c|}{$\begin{array}{l}\text { Add up scores from individual } \\
\text { risk factors }\end{array}$} & \\
\hline
\end{tabular}

Translating Static-99R scores into risk categories

\section{Score Label for Risk Category}

$\begin{array}{lll}-3 \text { through } 1 & = & \text { Low } \\ 2,3 & = & \text { Low-Moderate } \\ 4,5 & = & \text { Moderate-High } \\ 6 \text { plus } & = & \text { High }\end{array}$


Exhıвı r

REGISTRANT RISK ASSESSMENT SCALE

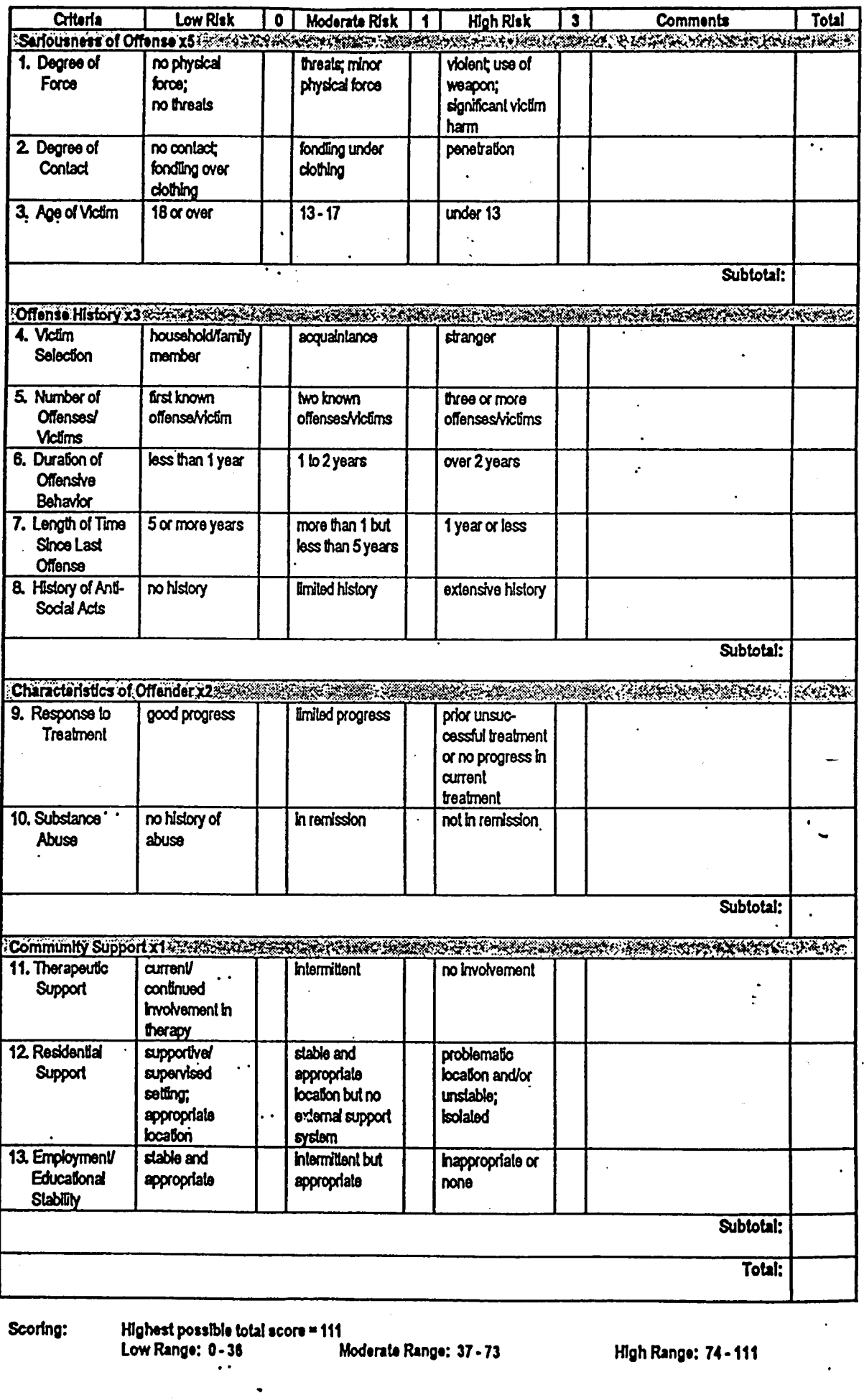

Table A.2: Number of Rape/Sexual Assaults in the United States: Self-Reports and Incidents, 1993-2006 


\begin{tabular}{|c|c|c|}
\hline \multicolumn{3}{|c|}{$\begin{array}{c}\text { Frequency of "Sexual Predator" and "Sex } \\
\text { Offender" In U.S. Newspaper Headlines, } \\
\text { Leads, \& Subject Terms, 1990-2006 }\end{array}$} \\
\hline Year & $\begin{array}{c}\text { Sexual Predator" } \\
\text { Term }\end{array}$ & $\begin{array}{c}\text { "Sex Offender" } \\
\text { Term }\end{array}$ \\
\hline 1990 & 57 & 354 \\
\hline 1991 & 42 & 264 \\
\hline 1992 & 60 & 473 \\
\hline 1993 & 104 & 585 \\
\hline 1994 & 380 & 1363 \\
\hline 1995 & 361 & 1836 \\
\hline 1996 & 689 & 2994 \\
\hline 1997 & 1286 & 3838 \\
\hline 1998 & 1659 & 4584 \\
\hline 1999 & 1789 & 5931 \\
\hline 2000 & 1157 & 4178 \\
\hline 2001 & 1282 & 4891 \\
\hline 2002 & 1882 & 6073 \\
\hline 2003 & 1728 & 7487 \\
\hline 2004 & 1865 & 8876 \\
\hline 2005 & 3029 & 13534 \\
\hline 2006 & 3993 & 12506 \\
\hline & Source: LexisNexis 2012 \\
\hline
\end{tabular}


Table A.2 Number of Rape/Sexual Assault in the United States: Self-Reports and Incidents, 1993-2006

\begin{tabular}{|c|c|}
\hline \multicolumn{2}{|c|}{$\begin{array}{c}\text { Number of Rape/Sexual Assaults in the } \\
\text { United States: Self-Reports and Incidents, } \\
1993-2006\end{array}$} \\
\hline Year & $\begin{array}{c}\text { Self-Reports of } \\
\text { Rape/Sexual Assault }\end{array}$ \\
\hline 1993 & 8.982 \\
\hline 1994 & 6.743 \\
\hline 1995 & 5.632 \\
\hline 1996 & 4.371 \\
\hline 1997 & 5.534 \\
\hline 1998 & 3.911 \\
\hline 1999 & 5.915 \\
\hline 2000 & 3.667 \\
\hline 2001 & 4.766 \\
\hline 2002 & 3.498 \\
\hline 2003 & 3.253 \\
\hline 2004 & 2.558 \\
\hline 2005 & 2.077 \\
\hline 2006 & 4.636 \\
\hline Source: Generated using the NCVS \\
Victimization Analysis Tool at \\
\hline www.bjs.gov. September 11, 2012 \\
\hline
\end{tabular}

